\title{
Heterogeneity of Soil Bacterial and Bacteriophage Communities in Three Rice Agroecosystems and Potential Impacts On Nutrient Cycling
}

Yajiao Wang

Chinese Academy of Agricultural Sciences

Yu Liu

Chinese Academy of Agricultural Sciences

Yuxing Wu

Hebei Academy of Agriculture and Forestry Sciences

Nan Wu

Chinese Academy of Agricultural Sciences

Wenwen Liu

Chinese Academy of Agricultural Sciences

Xifeng Wang ( $\nabla$ xfwang@ippcaas.cn)

Chinese Academy of Agricultural Sciences Institute of Plant Protection https://orcid.org/0000-0002-4982-8947

\section{Research Article}

Keywords: Paddy soil, Bacteriophage, Bacteriophage-bacteria interaction, Auxiliary metabolic genes, Nitrogen cycling

Posted Date: January 7th, 2022

DOl: https://doi.org/10.21203/rs.3.rs-1179635/v1

License: (c) (i) This work is licensed under a Creative Commons Attribution 4.0 International License. Read Full License

Version of Record: A version of this preprint was published at Environmental Microbiome on April 6th, 2022. See the published version at https://doi.org/10.1186/s40793-022-00410-8. 


\section{Abstract}

Background: As genetic entities infecting and replicating only in bacteria, bacteriophages can regulate the community structure and functions of their host bacteria, but they are often overlooked because of their relatively low abundance. The ecological roles of bacteriophages in aquatic and forest environments have been widely explored, but those in agroecosystems remains limited. Here, we used metagenomic sequencing to analyze the diversity and interactions of bacteriophages and their host bacteria in soils from three typical rice agroecosystems in China: double cropping in Guangzhou, southern China, rice-wheat rotation cropping in Nanjing, eastern China and early maturing single cropping in Jiamusi, northeastern China. Bacteriophages were isolated and their functions on soil nitrogen cycling and effect on soil bacterial community structure were verified in pot inoculation experiments and Illumina MiSeq sequencing.

Results: Soil bacterial and viral diversity and functions varied among the three agroecosystems. Genes detected in communities from the three agroecosystems were associated with typical functions; soil bacteria in Jiamusi were significantly enriched in genes related to carbohydrate metabolism, in Nanjing with xenobiotics biodegradation and metabolism, and in Guangzhou with virulence factors and scarce in secondary metabolite biosynthesis, which might lead to a significant occurrence of rice bacterial diseases. In the three ecosystems, 368 species of virus were detected. Notably, over-represented auxiliary carbohydrate-active enzyme (CAZyme) genes were identified in the viruses, which might assist host bacteria in metabolizing carbon, and $67.43 \%$ of these genes were present in Jiamusi. In bacteriophage isolation and inoculation experiments, Enterobacter bacteriophage-NJ reduced the nitrogen fixation capacity of soil by lysing $\mathrm{N}$-fixing host bacteria and changed the soil bacterial diversity and community structure.

Conclusions: Our results showed that diversity and function of paddy soil bacteria and viruses varied in the three agroecosystems. Soil bacteriophages can affect nutrient cycling by expressing auxiliary metabolic genes (AMGs) and lysing the host bacteria that are involved in biogeochemical cycles. These findings form a basis for better understanding bacterial and bacteriophage diversity in different rice agroecosystems, laying a solid foundation for further studies of soil microbial communities that support ecofriendly production of healthy rice.

\section{Background}

Rice, the primary staple food for about $60 \%$ of China's population [1] and planted in about 29.5 million ha in China, accounts for $35 \%$ of the total area planted in grain crops [2]. Rice-growing areas in China are quite diverse and distributed throughout most of the country and differ in ecological environment, cultivation methods and production levels. The three most important rice agroecosystems are rice double cropping in southern China ( $22 \%$ of total rice area), rice rotation with other crops in central and eastern China ( $59 \%$ of total) and early-maturing single cropping in northeastern China ( $9 \%$ of total). Southern China has a subtropical and marginal tropical monsoon climate, which is warm and rainy all year with long summers and short winters [3], 5800-7500 ${ }^{\circ} \mathrm{C}$ annual accumulated temperature, and about 300 days for rice growth, which is enough for double cropping. Central and eastern China belong to the climate in transition from subtropical to temperate zone, which is hot and rainy in summer but cold with less rain in winter with $4500-6500^{\circ} \mathrm{C}$ annual accumulated temperature and 210-260 days for plant growth, which is sufficient for rice rotation with other crops (wheat, oil rape, green manure or vegetables). However, northeastern China is at a high latitude with a temperate monsoon climate; it has a cold, long winter and warm, short summer. The annual accumulated temperature in this region is $2000-3700^{\circ} \mathrm{C}$, and the rice production season is $150-180$ days, long enough for only one rice crop. Flat terrain and fertile soil in this area, however, produce higher quality and yields of rice.

Different ecological environments and farming methods lead to different soil physicochemical properties and soil microbial diversity [4-6]. The hundreds of millions of soil microbes in soils include bacteria, fungi, archaea, viruses, that compete for nutrients and living space in the soil. Determining the physicochemical properties of soils and their effects on the soil microbial composition and diversity in different regions can help in utilizing local natural resources effectively and improving cultivation techniques to safely produce higher-yielding rice. Soil microbes not only breakdown organic matter and minerals, they also secrete secondary metabolites that can regulate plant growth [7-9]. Microbes in soil can cause disease or help protect against disease [10, 11]. Soil microbial communities and functions have strong spatial variability [12]. Bahram et al. (2018) found contrasting patterns in bacterial diversity in top soils across a latitudinal gradient around the world, with the highest diversity in temperate habitats, and environmental variables caused greater variation in microbial gene diversity than geographic distance did [13]. Soil microbial diversity and multifunctionality (decomposition and nutrient cycling, plant productivity) were demonstrated to be spatially specific and positively correlated in 78 global drylands and 179 locations across Scotland [14]. Elucidating spatial and temporal patterns of soil microbial diversity, community composition, and function will thus contribute to a better understanding of the generation and maintenance of microbial diversity, which will help to harness beneficial microbial resources for full use of their ecological functions in promoting healthy growth of plants in environmentally safe ecosystems.

Bacteriophages, which can infect and replicate within particular bacterial hosts, are also important components of soil microbial community, but are often overlooked due to their relatively low abundance [15]. However, they can regulate the community structure and function of bacteria and even the whole soil microbes [16]. Bacteriophages can modulate host bacterial populations and diversities by lysing bacterial cells [17], driving host evolution via bacteriophagemediated horizontal gene transfer [18], and altering host bacterial function by reprogramming their metabolism via the expression of virus-encoded auxiliary metabolic genes (AMGs) [19]. AMGs have a variety of metabolic functions, including in carbon, nitrogen and sulfur metabolism [20, 21], and photosynthesis [22]. However, most studies on the function of bacteriophages have focused on marine ecosystems or the human intestinal tract rather than soils in agroecosystems.

Our knowledge about paddy soil microbial diversity and function in different agroecosystems is also limited, and even less is known about viral communities and their roles. Studies of viruses in glacier soil [23], mangrove soil [24], mud volcanic soil [25], and Antarctic soil [26] revealed differences in soil viral community structure and largely uncharacterized viral assemblages. In the present study, we used metagenomic sequencing to analyze bacterial and viral community composition, diversity and ecological functions in paddy bulk soils in the three most important rice agroecosystems, double cropping in southern 
China, rice-wheat rotation cropping in central China, and early-maturing single cropping in northeastern China. We also tested the effects of bacteriophages on soil bacterial community structure and function in amended soils in pot experiments.

\section{Results}

\section{Soil microbial communities and differences in three rice agroecosystems}

In the metagenomic sequencing, 1.10 billion raw reads were obtained. After trimming, 1.07 billion clean reads remained. In Guangzhou, Nanjing and Jiamusi, $511,481,593,018,848,794$ contigs were obtained, respectively, after clean reads were assembled. Based on similarities to entries in the NCBI-NR database, $97.81 \%$ of sequences were classified as bacteria, $1.73 \%$ as Archaea, $0.27 \%$ as Eukaryota, and $0.026 \%$ as viruses. In total, 82 phyla, 1904 genera and 12,455 microbial species were identified. At the phylum level, Proteobacteria, Actinobacteria, Chloroflexi, Acidobacteria and Bacteroidetes were the top five mostabundant phyla, accounting for more than $78 \%$ of all the sequences (Fig. S1A). According to the LEfSe analysis (LDA $>3.5, p<0.05$ ), soils in Guangzhou and Nanjing were enriched in microbes belonging to Proteobacteria and Actinobacteria, respectively, while soils in Jiamusi were enriched in bacteria belonging to Chloroflexi, Acidobacteria and Bacteroidetes (Fig. 1A). At the generic level, there were significant differences in the dominant genera (with abundance greater than $1 \%$ and without unclassified genera). There were 10 dominant genera in Guangzhou, 13 in Nanjing and nine in Jiamusi, only $20 \%$ of the total dominant genera were shared by the three rice agroecosystems, and $45 \%$ were unique to a single rice agroecosystem (Fig. 1B, Table S3). The top three most-dominant genera were Gemmatimonas, Anaeromyxobacter and Candidatus Solibacter in Guangzhou, Nocardioides, Gemmatimonas and Solirubrobacter in Nanjing, Bradyrhizobium, Candidatus Solibacter and Anaeromyxobacter in Jiamusi (Fig. S1B). It is worth noting that none were shared by the three rice agroecosystems. Our results that the microbial community composition differed among the three rice agroecosystems was confirmed by PCoA analysis. The principal coordinate axis 1 (PCo1) and the principal coordinate axis 2 (PCo2) explained, respectively, 26.66\% and 19.22\% of the variation in bacterial species (Fig. S2).

\section{Complicated relationship between bacteriophage and bacterial abundance and diversity}

Viral and bacterial genes were selected out to analysis their relationship. Because of the low abundance of viruses, metagenomic sequencing only detected viruses that were relatively abundant. In total, 14 families, 29 genera and 368 species of viruses were identified. As in the most-often characterized viromes in various habitats, the annotated viruses in three rice agroecosystems belonged to families Siphoviridae, Podoviridae, Myoviridae, Phycodnaviridae and Herpesviridae. The relative abundance of Phycodnaviridae was highest in Jiamusi, and Siphoviridae, Podoviridae, Myoviridae and Herpesviridae were highest in Nanjing (Fig. 2A). Similar with the trend for the number of bacterial species, the number of viral species was highest in Nanjing ( 218 species), followed by Guangzhou (192 species) and Jiamusi (155 species). The three rice agroecosystems shared $13.39 \%$ of the total viral species, and $27.05 \%$ of the total viral species were shared by two agroecosystems; however, $59.56 \%$ of the viral species were specific to one agroecosystem (Fig. 2B).

Bacteriophages that infect the same bacterial genus were grouped together. We analyzed the correlation between the relative abundance of dominant bacteriophage groups (relative abundance greater than 1\%) and their host bacterial genera (Table 1). There were 19 dominant bacteriophage groups, the relative abundance of the hosts for three bacteriophage groups was greater than $1 \%$, less than $0.01 \%$ for four bacteriophage groups, and between $0.01 \%$ and $1 \%$ for 12 bacteriophage groups. Thus, the dominant bacteriophages were mainly distributed in bacteria with moderate abundance. The relationship between the relative abundance of the bacteriophages and that of their hosts is complex. The ratio of viral relative abundance to bacterial relative abundance (VBR) varies widely, between 0 and 27,382. But when VBR was greater than 100 in at least one of the three cropping systems, the abundance of bacteriophage and host bacteria was negatively correlated $\left(R^{2}<-0.5\right)$. 
Table 1

Correlation between the relative abundance of dominant bacteriophage groups and the host bacterial genera in the three rice agroecosystems

\begin{tabular}{|c|c|c|c|c|c|c|c|c|}
\hline Phages & NJ phage & NJ bacteria & NJ VBR & GZ phage & GZ bacteria & GZ VBR & JMS phage & JMS bacteria \\
\hline $\begin{array}{l}\text { Achromobacter } \\
\text { phage }\end{array}$ & $1.247 \pm 0.512$ & $0.845 \pm 0.035$ & 1.476 & $0.252 \pm 0.057$ & $1.370 \pm 0.039$ & 0.184 & 0 & $1.854 \pm 0.073$ \\
\hline Vibrio phage & $4.007 \pm 1.022$ & $0.024 \pm 0.001$ & 164.991 & $3.067 \pm 0.668$ & $0.031 \pm 0.0003$ & 98.523 & $0.254 \pm 0.149$ & $0.036 \pm 0.001$ \\
\hline Gordonia phage & $3.759 \pm 1.168$ & $0.080 \pm 0.003$ & 47.181 & $0.507 \pm 0.577$ & $0.058 \pm 0.002$ & 8.705 & $20.029 \pm 2.19$ & $0.043 \pm 0.001$ \\
\hline $\begin{array}{l}\text { Streptomyces } \\
\text { phage }\end{array}$ & $0.865 \pm 0.365$ & $1.977 \pm 0.056$ & 0.438 & $2.955 \pm 0.823$ & $1.127 \pm 0.059$ & 2.622 & $2.915 \pm 1.688$ & $1.136 \pm 0.066$ \\
\hline $\begin{array}{l}\text { Enterobacter } \\
\text { phage }\end{array}$ & $15.889 \pm 0.484$ & $0.005 \pm 0.0006$ & 3050.137 & $0.128 \pm 0.101$ & $0.008 \pm 0.0007$ & 15.398 & 0 & $0.007 \pm 0.001$ \\
\hline $\begin{array}{l}\text { Stenotrophomonas } \\
\text { phage }\end{array}$ & $7.319 \pm 1.331$ & $0.040 \pm 0.001$ & 184.654 & $3.905 \pm 1.262$ & $0.045 \pm 0.001$ & 87.197 & 0 & $0.044 \pm 0.0005$ \\
\hline Salmonella phage & $5.390 \pm 0.478$ & $0.002 \pm 0.0003$ & 2515.275 & $0.739 \pm 0.326$ & $0.003 \pm 0.0005$ & 252.934 & 0 & $0.003 \pm 0.0003$ \\
\hline $\begin{array}{l}\text { Paramecium } \\
\text { bursaria phage }\end{array}$ & $0.401 \pm 0.276$ & $0.0009 \pm 0.0002$ & 469.215 & $1.542 \pm 0.206$ & $0.0003 \pm 0.000007$ & 5020.489 & $10.980 \pm 1.297$ & $0.0004 \pm 0.000005$ \\
\hline $\begin{array}{l}\text { Rhodococcus } \\
\text { phage }\end{array}$ & $1.827 \pm 1.079$ & $0.393 \pm 0.012$ & 4.652 & $3.983 \pm 2.79$ & $0.196 \pm 0.009$ & 20.372 & $3.930 \pm 1.682$ & $0.181 \pm 0.012$ \\
\hline $\begin{array}{l}\text { Burkholderia } \\
\text { phage }\end{array}$ & $7.139 \pm 1.112$ & $0.226 \pm 0.003$ & 31.647 & $3.873 \pm 0.770$ & $0.347 \pm 0.005$ & 11.153 & $0.232 \pm 0.186$ & $0.232 \pm 0.002$ \\
\hline Caulobacterphage & $0.374 \pm 0.278$ & $0.087 \pm 0.004$ & 4.293 & $0.972 \pm 0.531$ & $0.099 \pm 0.002$ & 9.751 & $0.701 \pm 0.201$ & $0.058 \pm 0.002$ \\
\hline $\begin{array}{l}\text { Mycobacterium } \\
\text { phage }\end{array}$ & $8.404 \pm 7.98$ & $2.405 \pm 0.133$ & 3.495 & $5.269 \pm 0.545$ & $1.278 \pm 0.087$ & 4.122 & $5.679 \pm 1.066$ & $0.438 \pm 0.027$ \\
\hline Bacillus phage & $2.181 \pm 0.428$ & $0.214 \pm 0.002$ & 10.170 & $1.106 \pm 0.518$ & $0.240 \pm 0.002$ & 4.609 & $2.670 \pm 1.117$ & $0.282 \pm 0.005$ \\
\hline $\begin{array}{l}\text { Synechococcus } \\
\text { phage }\end{array}$ & $1.318 \pm 0.377$ & $0.059 \pm 0.0005$ & 22.252 & $2.990 \pm 0.831$ & $0.082 \pm 0.001$ & 36.361 & $3.436 \pm 1.065$ & $0.063 \pm 0.001$ \\
\hline $\begin{array}{l}\text { Pseudomonas } \\
\text { phage }\end{array}$ & $6.964 \pm 2.194$ & $0.247 \pm 0.013$ & 28.207 & $5.904 \pm 1.422$ & $0.334 \pm 0.007$ & 17.651 & $2.486 \pm 1.049$ & $0.207 \pm 0.002$ \\
\hline Ralstonia phage & $0.065 \pm 0.089$ & $0.063 \pm 0.002$ & 1.029 & $1.046 \pm 0.516$ & $0.117 \pm 0.0008$ & 8.933 & $0.501 \pm 0.102$ & $0.076 \pm 0.001$ \\
\hline Rhodoferax phage & 0 & $0.027 \pm 0.001$ & 0 & $1.392 \pm 0.386$ & $0.054 \pm 0.004$ & 25.709 & 0 & $0.044 \pm 0.0007$ \\
\hline $\begin{array}{l}\text { Actinoplanes } \\
\text { phage }\end{array}$ & $1.025 \pm 0.482$ & $0.298 \pm 0.007$ & 3.446 & $0.045 \pm 0.089$ & $0.147 \pm 0.009$ & 0.303 & $0.523 \pm 0.295$ & $0.173 \pm 0.011$ \\
\hline Arthrobacter phage & $4.391 \pm 0.892$ & $0.400 \pm 0.015$ & 10.969 & $2.286 \pm 0.579$ & $0.118 \pm 0.004$ & 19.392 & $16.613 \pm 1.227$ & $0.547 \pm 0.079$ \\
\hline
\end{tabular}

GZ: rice double cropping system in Guangzhou; JMS: rice single cropping system in Jiamusi; NJ: rice-wheat rotation cropping ecosystem in Nanjing. VBR: th abundance to bacterial relative abundance.

Metagenomic analysis of richness (represented by the Chao index) and diversity (represented by the Shannon index) revealed a significant difference in the bacterial and bacteriophage communities of paddy soils in different cropping systems. The Chao index showed that the bacterial richness in Nanjing was significantly higher than in Jiamusi and Guangzhou, while the difference between Jiamusi and Guangzhou was not significant. The viral richness was positively correlated with that of bacteria $\left(R^{2}=0.662, p=0.019\right)(F i g .3 \mathrm{~A})$, and the viral richness of Nanjing was significantly higher than that of Jiamusi and Guangzhou. The Shannon index analysis found that the diversity of Nanjing and Guangzhou did not differ significantly, but both were significantly higher than in Jiamusi. Viral diversity was negatively correlated with that of bacteria $\left(R^{2}=-0.876, p=0.001\right)$ (Fig. 3B).

\section{Soil bacterial function and its relationship with environment in three agroecosystems}

In the functional annotation of the soil metagenomic reads for the bacterial community using the Kyoto Encyclopedia of Genes and Genomes (KEGG) database, most sequences were associated with metabolism (70.24-72.38\%), and far fewer were involved in genetic information processing (8.44-8.93\%), environmental information processing (6.79-7.26\%), cellular processes (5.49-6.01\%), human diseases (3.93-4.57\%), and organismal systems (2.71\%-2.85\%). According to the LEfSe analysis (Fig. 4A), soil bacteria in Jiamusi were significantly enriched in genes associated with carbohydrate metabolism, replication and repair, biosynthesis of other secondary metabolites which were positively correlated with a high soil organic carbon (SOC) content (Fig. 4B; Table S2). While soil bacteria in Nanjing were significantly enriched in genes associated with xenobiotics biodegradation and metabolism, nucleotide metabolism, folding sorting and degradation, especially for genes involved in biodegradation and metabolism of nitrotoluene, aminobenzoate, naphthalene, steroid and xylene (Fig. S3). The annual frequency and dosage of chemical pesticide application especially herbicides in Nanjing were higher than those in other two areas (Table S2). As a result, pesticide residues in the soil were relatively high, and soils were significantly enriched in bacteria with xenobiotics biodegradation genes, presumably to help decompose pesticides in the soil. 
Soil bacteria in Guangzhou were significantly enriched in genes associated with bacterial virulence, energy metabolism, translation, cell growth and death, which were positively correlated with annual accumulated temperature and annual precipitation. In the field disease evaluation, we found that the disease indices for rice brown spot, brown streak, bacterial blight, bacterial leaf streak and foot rot were the highest in Guangzhou (Fig. 5A). Similarly, the relative abundance of the pathogenic bacteria Pseudomonas syringae, Acidovorax avenae, Xanthomonas oryzae and Dickeya zeae was significantly higher in Guangzhou than in Jiamusi and Nanjing (Fig. 5B) and was positively correlated with temperature and humidity $\left(R^{2}>0.5, p<0.05\right)$. In addition, the analysis of the virulence factor database VFDB showed that the abundance of genes related to factors (adherence-related genes) in the Guangzhou region was significantly higher than that in Nanjing and Jiamusi, especially for genes for flagella, Trw type IV secretion system, fimbriae, Myf/pH6 antigen, and PI-2, accounting for more than $70 \%$ of the total adherence-related genes (Fig. $5 \mathrm{C}$ ). Functional analysis of biosynthesis of other secondary metabolites showed that the genes related to antimicrobial antibiotic secretion (such as biosynthesis of streptomycin, penicillin and cephalosporin, and neomycin, kanamycin and gentamicin) in Guangzhou were significantly lower compared with that of Nanjing and Jiamusi (Fig. 5D). Bacterial diseases may be more serious in Guangzhou due to the higher temperature and humidity and lower secretion of antibiotics, which may be conducive to the reproduction of pathogenic bacteria and to the higher relative abundance of adherence-related genes might aid their infection of the plant host.

\section{Abundant auxiliary carbohydrate metabolic genes in paddy viruses}

In the functional annotation of viruses in paddy soils using the KEGG database (Fig. 6A), almost all functions in pathway level 2 were found, but the sequences were notably enriched in a limited number of functions; the top three assigned functions accounted for $70 \%$ of the annotated sequences. The top two most-abundant functions were nucleotide metabolism, replication and repair, which are critical for the reproduction and survival of viruses. In addition, viruses have genes related to carbohydrate metabolism and the biosynthesis of secondary metabolites; the relative abundances of genes related to carbohydrate metabolism in viruses were negatively correlated $\left(R^{2}=-0.498, p=0.334\right)$ with those in soil bacteria (Fig. S4A). Similarly, the abundances of genes related to biosynthesis of secondary metabolites in viruses were negatively correlated $\left(R^{2}=-0.500, p=0.333\right)$ with those in soil bacteria (Fig. S4B). These two types of genes carried by bacteriophages might assist host bacteria in carbon metabolism and secondary metabolite synthesis. In the annotation of carbohydrate-active enzymes (CAZymes) using the CAZy database (Fig. 6B), the species and abundance of viral CAZymes differed significantly among the soils of the three cropping systems. Notably, $67.43 \%$ of the CAZymes-related genes were present in Jiamusi, which was 9.83 and 2.62 times higher than in Guangzhou and Nanjing. In addition, there were two classes CAZymes (glycoside hydrolases, glycosyl transferases) in Guangzhou, two classes (glycoside hydrolases, carbohydrate-binding modules) in Nanjing, but four classes (glycoside hydrolases, carbohydrate-binding modules, glycosyl transferases, polysaccharide hydrolase) in Jiamusi. Remarkably, polysaccharide lyases (pectate lyase, exopolygalacturonate lyase, thiopeptidoglycan lyase) were unique to Jiamusi, implying potential roles in the decomposition of soil organic carbon.

\section{Enterobacter bacteriophages can reduce the nitrogen fixation capacity of soil by lysing host bacteria}

In Nanjing, the most abundant bacteriophage was Enterobacter phage, with a relative abundance of $15.28 \%$, compared with $0.13 \%$ in Guangzhou and $0 \%$ in Jiamusi (Fig. S5A). They were also negatively correlated with the abundance of host bacteria Enterobacter $\left(R^{2}=-0.805, p=0.404\right)($ Fig. S5B). To study its function, the bacteriophage was isolated from the soil in Nanjing and named Enterobacter phage-NJ (Fig. S6A). In the plate lytic experiment, the bacteriophage had lytic activity against nitrogen-fixing Enterobacter (Fig. S6B).

To assess the functional effects of Enterobacter phage-NJ on nitrogen fixation and uptake, we added Enterobacter phage-NJ to the sterilized soil to which nitrogen-fixing Enterobacter had been added. The results showed that the nitrogen-fixation capacity decreased by 55\%, and plant height, fresh mass and nitrogen content of the rice plants were $14.27 \%, 32.25 \%$, and $37.17 \%$, respectively, lower than in the controls (Fig. 7B). Similar results were found when Enterobacter phage-NJ was added to untreated field soil; the nitrogen-fixation capacity decreased by $16.49 \%$, and plant height, fresh mass, and nitrogen content were $9.29 \%, 17.97 \%$, and $18.58 \%$, respectively, lower than in the controls (Fig. 7C).

Rhizosphere microbial diversity in untreated field soil after the addition of Enterobacterphage-NJ was then studied using $16 \mathrm{~S}$ amplicon sequencing. After the addition of Enterobacter phage-NJ, the richness and diversity of rice rhizosphere microorganisms was $29.97 \%$ and $19.17 \%$, respectively, lower than in the control (Fig. S7A). Moreover, the community structure of rhizosphere microorganisms significantly changed; PCoA demonstrated separate clustering (Fig. S7B). In addition, the metabolic function of rhizosphere microorganisms also significantly decreased, especially carbohydrate metabolism, energy metabolism and biosynthesis of secondary metabolites (Fig. S7C).

\section{Discussion}

\section{Functional differences of soil bacteri a in the three rice agroecosystems}

Soil bacteria in three rice agroecosystem performed multiple functions simultaneously and were significantly enriched in typical functions that were specific for an agroecosystem. Soil bacteria in Jiamusi and Nanjing were significantly enriched in genes associated with carbohydrate metabolism, xenobiotics biodegradation and metabolism, respectively, while soil bacteria in Guangzhou were enriched in genes associated with virulence factors, but scarce in genes associated with secondary metabolite biosynthesis, which might lead to the significant occurrence of rice bacterial diseases. These significant differences are likely related to the local environment and cropping system. The effects of environment on soil bacterial function can be divided into direct and indirect effects. Environmental factors especially temperature can directly influence the functions by accelerating the activity microbes $[27,28]$ or indirectly affect functions by altering the composition of microbial communities [29]. Soils in Jiamusi were significantly enriched in genes associated with carbohydrate

Page 5/16 
metabolism, which were positively correlated with the high content of soil organic matter. Soil organic matter can provide nutrients and promote multiplication of microbes, ultimately, indirectly promoting the capacity of carbon metabolism. With lower inputs of plant-derived organic carbon, desert communities have lower relative abundances of genes associated with nutrient cycling and the catabolism of plant-derived organic compounds compared with forests, grasslands, and tundra [30]. Our correlation analysis of environment and function showed that soil bacteria in Nanjing were significantly enriched in genes associated with xenobiotics biodegradation and metabolism, which were positively correlated with the large number of pesticide applications. Because of the rice-wheat rotation system in Nanjing, more types and applications of chemicals are used than in the double cropping system in Guangzhou and in the single cropping rice in Jiamusi. Chemical residues are beneficial to the survival of pesticide-degrading microbes and ultimately result in significant enrichment of the xenobiotics biodegradation and metabolism functions of soil bacteria in Nanjing. The genes associated with bacterial virulence factors in Guangzhou soils were positively correlated with higher annual accumulated temperature and annual precipitation. One of the most important conditions for rice bacterial diseases is high temperature and humidity [31]. In addition, double cropping rice in Guangzhou provides two growing seasons for hosts of bacterial pathogens, so pathogens have more time and opportunity to survive than Nanjing and Jiamusi. These results indicate that functions of soil bacteria vary in different agroecosystems and that environmental factors play important roles through affect microbial community composition.

\section{Differences in soil viruses among the three agroecosystems and their relationship with host bacteria}

In our study, there were significant differences in the species and composition of paddy soil viruses among the three agroecosystems. In Nanjing, $40.64 \%$ more virus species were detected than in Jiamusi and $13.54 \%$ more than in Guangzhou. A previous study showed that the bacterial host species and abundance may be a key factor controlling viral abundance and distribution [32]. Similarly, we found that soil viral richness was significantly positively correlated with bacterial richness $\left(R^{2}=0.662, p=0.01\right)$. Only $13.39 \%$ of the viral species were shared by all three rice agroecosystems, while $59.56 \%$ of the viral species were environmentally specific, which is likely associated with the significant differences in temperature, annual precipitation and soil physicochemical properties in the three rice agroecosystems because viral diversity and community structure have been reported to be controlled by factors such as temperature [33], soil moisture [34], and pH [35].

In soils, most viruses are bacteriophages, which can be divided into lysogenic or lytic bacteriophages. The abundance and distribution of bacteriophages and host bacteria influence each other in a complex relationship based on our results. Bacteriophages are obligate intracellular parasites, so their fitness and range limits are influenced by their hosts, and the bacteriophages in turn can affect host abundance and even the community structure and diversity of the whole bacterial community [36-38]. Lytic bacteriophages can modulate host bacterial populations and diversities by lysing their hosts [16], but lysogenic bacteriophages can increase the host abundance by promoting horizontal gene transfer by lysogenic conversion or transferring packaged bacterial genes to new hosts, which may expand the host metabolic profile and enhance microbial environmental adaptability [39]. The ratio of viral abundance to bacterial abundance (VBR) has been used as means to infer relationships between viruses and their potential hosts [40]. Lower VBRs means low virion production, and lysogeny is thus considered to be common. Conversely, higher VBR means higher virion production, and lysogeny is considered to be less prevalent; bacteriophages may thus be primarily lytic [41]. In cold deserts, the VBR ranged from 0.15 to 1.66 , and the prevalence of bacterial lysogens was between 4.6 and $21.1 \%[42,43]$, while in hot deserts, the VBR ranged from 170 to 8,200 , and the prevalence of bacterial lysogens was $84 \%$, much higher than in the cold desert soils [44]. In our analysis of the ratio of viral relative abundance to bacterial relative abundance, similar to the results of previous studies [41, 42, 44]; when the ratio was greater than 100 , there was a significant negative correlation between the abundance of bacteriophage and bacteria, indicating that bacteriophages may be lytic, which negatively regulates the abundance of host bacteria. However, when the ratio was less than 100 , the correlation between bacteriophage and bacteria abundance was not significant, perhaps because the bacteriophages may be lysogenic, which have little effect on host bacteria abundance, and/or because bacteriophages overlap in their distribution with multiple susceptible hosts in natural environment, while bacteria can often be infected with several different types of bacteriophages. Furthermore, many factors influence the abundance of bacteriophages and host bacteria, making the relationship between them more complex.

\section{Bacteriophages inhibit soil nitrogen fixation by lysing host bacteria}

Lytic bacteriophages have direct and indirect effects on nutrient cycling. They can directly lyse bacteria, which releases organic matter, including nutrients such as carbon, nitrogen and phosphorus. The carbon cycle driven by viruses accounts for $25 \%$ of the total carbon cycle in marine agroecosystems [16]. Addition of bacteriophages to soil also increases the $\mathrm{NH}_{4}{ }^{+}$concentration via lysis, resulting in a release of inorganic nitrogen, followed by mineralization [45]. Indirectly, bacteriophage lysis can also slow nutrient transformations by reducing the population of key bacteria involved in nutrient cycling [45]. Higher abundance of T4-like phages increases bacterial death, thereby suppressing soil organic carbon mineralization [46]. In wetlands, bacteriophages can infect sulfate-reducing and methanogenic bacteria, which can potentially repress sulfate reduction (and associated carbon mineralization) and methane production, respectively [47]. However, indirect inhibition of biogeochemical cycling by bacteriophages has mostly been inferred by sequencing analysis without relevant experimental verification. In our study, Enterobacter phage-NJ, which was isolated from the soil in Nanjing, lysed three species of nitrogen-fixing Enterobacter bacteria. When Enterobacter phages-NJ were added to untreated field soil or sterilized soil with nitrogen-fixing bacteria, the soil nitrogen-fixation capacity decreased, and rice growth and nitrogen content decreased also. This result provides direct evidence that bacteriophages can inhibit biogeochemical cycling through lysis. Enterobacter phage phiEap-2 was the most abundant in the tested soils from Nanjing, with a relative abundance of $15 \%$. When we extracted all viruses from the Nanjing soils and added them into natural field soil, the result was similar to adding bacteriophages alone; that is, soil nitrogen-fixation capacity was reduced. In addition, the soil microbial community changed, and the bacterial metabolic functions such carbon metabolism and energy metabolism decreased also. These results indicate that bacteriophages can regulate soil bacterial community structure and ecological function and that the differences in soil bacterial function were related to differences in the bacteriophages in the different agroecosystems.

\section{Potential effects of auxiliary metabolic genes of phages on soil microbial function}


Bacteriophages can affect nutrient cycling not only by lysing the host but also by metabolically reprogramming their hosts via the horizontal transfer of ecologically important genes and the expression of virus-carried auxiliary metabolic genes (AMGs) [48]. AMGs have been most extensively explored in marine ecosystem and are involved in photosynthesis, carbon metabolism, nitrogen metabolism and phosphate uptake [21]. Those genes are hypothesized to increase viral survival and replication by augmenting key steps in host metabolism. Cyanobacteria can photosynthesize in the ocean to obtain energy for growth, but they are susceptible to photoinhibition when sunlight is too intense. Cyanobacteria bacteriophage S-PM2 carries $p s b A$ and $p s b D$ genes, which encode proteins D1 and D2, key components of photosystem II, which are crucial sites of damage in photoinhibition. Bacterial infection with bacteriophage SPM2 ensures that photoinhibition is prevented, thereby maintaining photosynthetic activity and energy production for the continued replication of the bacteriophage [18]. Marine viruses contain carbon metabolic genes that encode numerous enzymes involved carbon metabolism and have been shown to increase metabolic flux when glucose is limited $[49,50]$. Bacteriophages in different ocean environments also harbor niche-specific AMGs. For example, in sunlit ocean water, photosynthesis-related genes are the main AMGs, but in dark ocean water, genes involved in the tricarboxylic acid cycle and electron transport chain prevail [49].

In mangrove soil [24], permafrost soil [51], and maize-barley rotation soil [20], AMGs involved in carbohydrate metabolism are notably over-represented. In the maize-barley rotation soil, three classes of genes-carbohydrate-binding modules, carbohydrate esterases, glycoside hydrolases-were identified. Similarly, in paddy soil, four classes of AMGs of bacteriophages involved in carbon metabolism were identified in our study (glycoside hydrolases, glycosyl transferases, polysaccharide lyases, and carbohydrate-binding modules, with the abundance of glycoside hydrolases the highest), indicating that paddy soil viruses primarily participate in the decomposition of organic carbon, breakdown of complex carbohydrates to increase energy production and boost bacteriophage replication. The species and abundance of AMGs also differed among the three agroecosystems we studied. Compared with the bacteriophages in the other two agroecosystems, the bacteriophages in Jiamusi had the greatest diversity of AMGs genes related to carbon metabolism; there were four classes of CAZymes in Jiamusi (polysaccharide lyases, glycoside hydrolases, glycosyl transferases, carbohydrate-binding modules), but only two in Guangzhou (glycoside hydrolases, glycosyl transferases) and in Nanjing (glycoside hydrolases, carbohydrate-binding modules). However, soil bacteria in Jiamusi were significantly enriched for carbon metabolism function, likely due to the large diversity of bacteriophage AMGs genes related to carbon metabolism. Remarkably, polysaccharide lyases (pectate lyase, exopolygalacturonate lyase, thiopeptidoglycan lyase) were unique to Jiamusi. Complex carbohydrates or polysaccharides such as cellulose, xylan, pectin, starch, alginate, mannan, and chitin are major components of plant cell walls, which are difficult to degrade. In Jiamusi, the soil organic matter content is the highest, perhaps because the bacteriophages carry genes for polysaccharide lyases, which might assist host bacteria in degrading organic matter in the soil.

\section{Conclusions}

In our analyses to identify and compare the bacterial and viral communities in soils from the three most important rice agroecosystems in China, the communities in Jiamusi were significantly enriched in genes related to carbohydrate metabolism, in Nanjing with xenobiotics biodegradation and metabolism, and in Guangzhou with genes associated with virulence factors, but those involved with secondary metabolite biosynthesis were scarce, which might lead to a significant incidence of rice bacterial diseases. The 368 virus species that were detected from the three agroecosystems likely affect the soil microbial community structure and function. Bacteriophage isolation and inoculation experiments showed that Enterobacter phage-NJ not only changed the soil bacterial diversity and community structure, but also reduced the nitrogen-fixation capacity by lysing nitrogen-fixing host bacteria. In addition, auxiliary carbohydrate-active enzyme (CAZyme) genes were notably over-represented in soil viruses, and $67.43 \%$ of all CAZyme genes were present in Jiamusi soils, which might assist host bacteria in metabolizing carbon. Our study will contribute to a better understanding of the microbial diversity in the typical rice agroecosystems in China, viral mechanisms that may be involved in this diversity and inform management programs for the safe production of healthy rice.

\section{Methods}

\section{Sampling sites and sample collection}

Paddy soil samples were collected during heading of rice in 2019 from long-term (more than 20 years) rice farms in Jiamusi ( $46^{\circ} 48^{\prime} \mathrm{N}, 130^{\circ} 22^{\prime} \mathrm{E}, 130 \mathrm{~m}$ a.s.I.) in Heilongjiang Province, Nanjing ( $30^{\circ} 02^{\prime} \mathrm{N}, 118^{\circ} 46^{\prime} \mathrm{E}, 30 \mathrm{~m}$ a.s.l.) in Jiangsu Province, and Guangzhou (2313' N, $113.27^{\prime} \mathrm{E}, 871 \mathrm{~m}$ a.s.l.) in Guangdong Province in China. In Jiamusi, Nanjing and Guangzhou, the annual precipitation is $510 \mathrm{~mm}, 1090 \mathrm{~mm}$ and $1720 \mathrm{~mm}$, respectively, with $67 \%$, $73 \%$, and $77 \%$ mean humidity, respectively, and the annual accumulated temperature of $2700^{\circ} \mathrm{C}, 5400^{\circ} \mathrm{C}$ and $7500^{\circ} \mathrm{C}$, respectively (http://www.weather.com.cn). The three regions different in their rice planting systems (single rice cropping in Jiamusi, rice-wheat rotation in Nanjing, double rice cropping in Guangzhou). Rice was grown at each farm using local practices for cultivation, fertilizer application, and field management. Chemical pesticides were applied as shown in Table S1. Four plots $(5 \times 10 \mathrm{~m})$ were randomly selected for collecting 30 cores of bulk soil samples $(0-15 \mathrm{~cm})$ at each farm. At the same time, plants were inspected for naturally occurring diseases in four randomly chosen, representative 5-m lengths of rows from each plot. The severity of rice leaf diseases (rice brown spot, brown streak, bacterial blight, bacterial leaf streak and foot rot) was visually scored on a 0 to 5 scale based on the estimated percentage leaf area with lesions: 0 , no symptoms; $1,0.1-6 \%$ of total leaf area; $2,7-12 \% ; 3,13-25 \% ; 4,26-50 \% ; 5,51-100 \%$ [52]. A disease severity index was then calculated as $\sum$ (Number of diseased plants with each score $\times$ Highest score) $/$ (Total number of plants $\times$ Highest score) $\times 100$. Disease incidence of rice bacterial foot rot was investigated as the (Number of plants with blackened, rotting roots / Total number of examined plants) $\times 100$. Soil samples were transported to the laboratory on ice in a cooler. A portion of the soil sample was stored at $-80^{\circ} \mathrm{C}$ for DNA extraction, and the remainder was stored at $4{ }^{\circ} \mathrm{C}$ for analyses of soil chemical properties.

\section{Analyses of soil chemical properties}

Soil pH was determined using a Mettler-Toledo FE20-Five Easy PlusTM pH meter (Schwerzenbach, Switzerland) in a 1:5 soil-water (w/v) suspension. Soil organic carbon was measured using the chromic acid titration method [53]. Soil available nitrogen was determined by the alkali diffusion method, soil 
available phosphorus was determined using the sodium hydrogen carbonate solution-Mo-Sb anti spectrophotometric method, soil available potassium was measured by the ammonium acetate method, followed by flame photometric detection [54].

\section{DNA extraction}

Microbial genomic DNA was extracted from $0.5 \mathrm{~g}$ soil with the E.Z.N.A. Soil DNA Kit (Omega Bio-TEK, Norcross, GA, USA) according to the manufacturer's instructions. Concentration and purity of extracted DNA were determined with a TBS-380 Mini-Fluorometer (Turner Biosystems, CA, USA) and NanoDrop2000 UV-Vis spectrophotometer (Thermo Scientific, Wilmington, DE, USA), respectively. DNA quality was confirmed using $1.2 \%$ agarose gel electrophoresis, with $1 \times$ TAE buffer (40 mM Tris- $\mathrm{HCl}, 40 \mathrm{mM}$ acetate, $1.0 \mathrm{mM} \mathrm{EDTA})$ and ethidium bromide $\left(0.5 \mu \mathrm{g} \mathrm{mL}^{-1}\right)$ under ultraviolet light [55].

\section{Shotgun metagenomic analysis}

The extracted DNA was fragmented to an average size of about 400 bp using Covaris M220 (Gene Company Limited, Hong Kong, China). A paired-end library was constructed using NEXTFLEX® Rapid DNA-Seq (Bioo Scientific, Austin, TX, USA). Paired-end sequencing was performed using the Illumina HiSeq 4000 platform (Illumina Inc., San Diego, CA, USA) at Majorbio Bio-Pharm Technology Co., Ltd. (Shanghai, China), HiSeq 3000/4000 PE Cluster Kit and HiSeq $3000 / 4000$ SBS Kit according to the manufacturer's instructions (www.illumina.com). Sequence data associated with this project were deposited in the NCBI Short Read Archive database (accession PRJNA732820). The paired-end Illumina reads were trimmed of adaptors, and low-quality reads (length < 50 bp or with a quality value $<20$ or having $\mathrm{N}$ bases) were removed by fastp version 0.20 .0 (https://github.com/OpenGene/fastp). Metagenomics data were assembled using MEGAHIT (https://github.com/voutcn/megahit, version 1.1.2). Contigs of 3300 bp were selected for further gene prediction and annotation. BLASTP against the NCBI NR database was used for taxonomic annotations of the representative sequences with an e-value cut-off $1 \mathrm{e}^{-5}$ using Diamond (http://www.diamondsearch.org/index.php, version 0.8.35). The KEGG annotation was conducted using Diamond against the Kyoto Encyclopedia of Genes and Genomes (KEGG) database (http://www.genome.jp/keeg/) with an e-value cutoff of $1 \mathrm{e}^{-5}$. Virulence factors were annotated using the VFDB database (http://www.mgc.ac.cn/VFs/) with an e-value cutoff of $1 \mathrm{e}^{-5}$. Carbohydrate-active enzymes were identified using HMMscan tools and the Carbohydrate[1]Active enZYmes Database (CAZy) with an e-value cutoff of $1 e^{-5}$. We also selected the bacterial and viral genes and built a viral set for taxonomic, KEGG and CAZY annotations.

\section{Isolation of soil viruses}

Soil sample $(1 \mathrm{~kg})$ was suspended in $1 \mathrm{~L}$ of SM solution $\left(100 \mathrm{mM} \mathrm{NaCl}, 8 \mathrm{mM} \mathrm{MgSO}{ }_{4} \cdot 7 \mathrm{H}_{2} \mathrm{O}\right.$ and $\left.50 \mathrm{mM} \mathrm{Tris} / \mathrm{HCl}, \mathrm{pH} 7.5\right)$ and shaken for $2 \mathrm{~h}$ at $30^{\circ} \mathrm{C}$. The soil particles were removed by centrifugation at $4000^{\prime} \mathrm{g}$ for $15 \mathrm{~min}$. The supernatant was filtered sequentially through 0.45 and $0.22 \mu \mathrm{m}$ filters. Then, virus particles in the filtered supernatant were concentrated into $1 \mathrm{~mL}$ by centrifugation at $4000^{\prime} \mathrm{g}$ in $100 \mathrm{kDa}$ centrifugal ultrafiltration tubes.

\section{Isolation of Enterobacter bacteriophage from paddy soil}

Soil sample ( $10 \mathrm{~g}$ ) was suspended in $50 \mathrm{~mL}$ Luria Bertani (LB) broth ( $1 \%$ tryptone, $0.5 \%$ yeast extract, and $1 \% \mathrm{NaCl})$ and dispersed by shaking for $12 \mathrm{~h}$ at $30^{\circ} \mathrm{C}$. The soil particles were removed by centrifugation at $4000^{\prime} \mathrm{g}$ for $15 \mathrm{~min}$, and the supernatant was filter-sterilized through a $0.22 \mu \mathrm{m}$ filter. One milliliter of filtered supernatant was added to $10 \mathrm{~mL}$ of an overnight suspension culture of Enterobacter cloacae (proven to be nitrogen-fixing and provided by Agricultural Culture Collection of China) and incubated for $12 \mathrm{~h}$ at $30^{\circ} \mathrm{C}$ [56]. Then bacterial cells were removed by centrifugation at 4000 ' $g$ for $15 \mathrm{~min}$, and the supernatant was sterilized through a $0.22 \mu \mathrm{m}$ filter. Then $0.1 \mathrm{~mL}$ of the filtered supernatant was mixed with $1 \mathrm{~mL}$ of the $E$. cloacae suspension (OD600 $=1$ ). This mixture was then added to $2.5 \mathrm{~mL}$ of soft agar ( $0.35 \%$ agar prepared in $1 \%$ tryptone, $0.5 \% \mathrm{NaCl}, 3 \mathrm{mM} \mathrm{MgCl}_{2}, 3 \mathrm{mM} \mathrm{CaCl}_{2}$, and $0.04 \%$ [wt / vol] glucose) and poured in a uniform layer onto an LB agar plate. Bacteriophage plaques were identified after an overnight incubation at $30^{\circ} \mathrm{C}$. Bacteriophages were purified via five consecutive transfers of them from individual plaques to new bacterial cell lawns. The purified bacteriophage titer was determined by mixing $100 \mu \mathrm{L}$ of host cells (A600 of 1) and $100 \mu \mathrm{L}$ of bacteriophage dilution with soft agar and pouring the mixture over LB agar in a plate. Plaques were scored after an overnight incubation at $30^{\circ} \mathrm{C}$. Bacteriophages were kept in buffer $\left(10 \mathrm{mM}\right.$ Tris [pH 7.6], $5 \mathrm{mM} \mathrm{MgSO}{ }_{4} \cdot 7 \mathrm{H}_{2} \mathrm{O}, 0.01 \%$ gelatin) at $4{ }^{\circ} \mathrm{C}$.

Each isolated Enterobacter phage was analyzed for its ability to lyse $E$. ancerogenus and $E$. ludwigii (proven to be nitrogen-fixing and provided by Agricultural Culture Collection of China) using a plate lytic experiment with $0.1 \mathrm{~mL}$ bacteriophage mixed with $1 \mathrm{~mL}$ of overnight-cultured Enterobacter strain and shaken (200 rpm) at room temperature for $20 \mathrm{~min}$, then $3 \mathrm{~mL}$ of soft nutrient agar was added, and the mixture was poured on LB agar plates and incubated overnight at $30^{\circ} \mathrm{C}$. Lytic activity was indicated by transparent plaques [57].

\section{Impact of Enterobacter bacteriophages on soil nitrogen-fixation capacity}

In a greenhouse experiment, the influence of Enterobacter phages on soil nitrogen fixation capacity in untreated field soil and in sterilized field soil was investigated. Rice seeds were surface-sterilized and pregerminated, then seedlings with a primary root length of $1-2 \mathrm{~cm}$ were planted in pots (6 seeds per pot) with the untreated field soil. Three treatments with four pots each (each pot filled with $1 \mathrm{~kg}$ soil) were set up: (1) N+NJ virus, virus isolated from $1 \mathrm{~kg}$ Nanjing soil was diluted 50 times with $\mathrm{ddH}_{2} \mathrm{O}$ and added to each pot after planting rice; (2) N+phage, $1 \mathrm{~mL}$ Enterobacter bacteriophages (10 7 PFUs) diluted 50 times

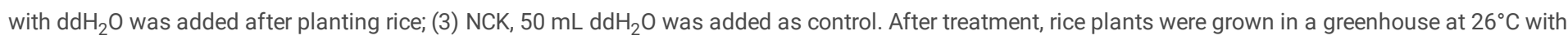

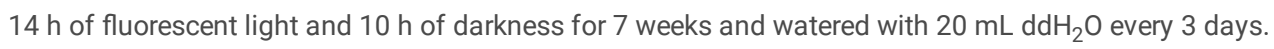

Untreated field soil was autoclaved using the liquid cycle for $30 \mathrm{~min}$ at $121^{\circ} \mathrm{C}$, then cooled at room temperature, then we repeated this procedure, sterilized soil was stored at $4{ }^{\circ} \mathrm{C}$ until use. Mixed Enterobacter species (E. cloacae-211, E. ancerogenus-212, E. ludwigii-213, ratio 1:1:1) were cultured in LB broth overnight at $30^{\circ} \mathrm{C}$, followed by centrifugation at 1,000 ' $\mathrm{g}$ for $5 \mathrm{~min}$. The pellet was resuspended in $\mathrm{ddH}_{2} \mathrm{O}$ and diluted to an optical density $\mathrm{OD} 600$ of 0.02 . Rice seeds were surface-sterilized and pregerminated, then seedlings with primary root length of $1-2 \mathrm{~cm}$ ) were planted in pots (6 seeds per pot) with sterilized soil. Four 
treatments were set up with four pots per treatment: (1) S+NF, $50 \mathrm{~mL}$ Enterobacter strains were added after rice planting, then cultured for a week and added with $\mathrm{ddH}_{2} \mathrm{O}$; (2) S+NF+virus, $50 \mathrm{~mL}$ Enterobacter strains were added after rice planting, then cultured for a week and added with virus isolated from $1 \mathrm{~kg}$ Nanjing soil, which was diluted to $50 \mathrm{~mL}$ with $\mathrm{ddH}_{2} \mathrm{O}$; (3) S+NF+phage, $50 \mathrm{~mL}$ Enterobacter strains were added after rice planting, then cultured for a week and watered with $1 \mathrm{~mL}$ Enterobacter bacteriophages (107 PFUs) was diluted to $50 \mathrm{~mL}$ with dd $\mathrm{H}_{2} \mathrm{O}$; (4) SCK, sterile water was used as the control. After treatment, rice plants were grown in a greenhouse at $26^{\circ} \mathrm{C}$ with $14 \mathrm{~h}$ of fluorescent light and $10 \mathrm{~h}$ of darkness for 7 weeks and watered with $20 \mathrm{~mL}$ dd $\mathrm{H}_{2} \mathrm{O}$ every 3 days. After 7 weeks, rice height and fresh mass were measured. Then rice plants were dried and grounded, nitrogen concentrations were determined with a modified Kjeldahl digestion method. $\mathrm{N}_{2}$ fixation in soil samples was assessed indirectly using the acetylene reduction assay measuring ethylene formation from acetylene.

\section{Illumina MiSeq sequencing}

Region V3-V4 of the bacterial 16S rRNA gene was amplified from each sample using primers 338F (5'-ACTCCTACGGGAGGCAGCAG-3') and 806R (5'GGACTACHVGGGTWTCTAAT-3') in a thermocycler PCR system (GeneAmp 9700, ABI, Foster, CA, United States); barcode was added before the primer to build different libraries in the same sequencing pool. The PCR mixture contained $4 \mu \mathrm{L} 5 \times$ TransStart FastPfu buffer, $2 \mu \mathrm{L} 2.5 \mathrm{mM}$ dNTPs, $0.8 \mu \mathrm{L} 5 \mu \mathrm{M}$ forward primer, $0.8 \mu \mathrm{L} 5 \mu \mathrm{M}$ reverse primer, $0.4 \mu \mathrm{L}$ TransStart FastPfu DNA Polymerase, $10 \mathrm{ng}$ template DNA, with ddH $\mathrm{H}_{2} \mathrm{O}$ added to reach $20 \mu \mathrm{L}$. PCR cycling conditions were initial denaturation at $95^{\circ} \mathrm{C}$ for $3 \mathrm{~min} ; 35$ cycles of denaturing at $95^{\circ} \mathrm{C}$ for $30 \mathrm{~s}$, annealing at $55^{\circ} \mathrm{C}$ for $30 \mathrm{~s}$ and extension at $72{ }^{\circ} \mathrm{C}$ for $45 \mathrm{~s}$; and single extension at $72^{\circ} \mathrm{C}$ for $10 \mathrm{~min}$, and end at $4^{\circ} \mathrm{C}$. The PCR product was extracted from $2 \%$ agarose gel and purified using the AxyPrep DNA Gel Extraction Kit (Axygen Biosciences, Union City, CA, USA), then quantified using a Quantus Fluorometer (Promega, Madison, WI, USA). Purified amplicons were paired-end sequenced $(2 \times 300)$ on an Illumina MiSeq platform (Illumina, San Diego, CA, USA) according to standard protocols by Majorbio Bio-Pharm Technology Co. Ltd. (Shanghai, China). The raw reads were deposited in the NCBI Sequence Read Archive (SRA) database (accession No. PRJNA780198).

The raw sequencing reads were demultiplexed, quality-filtered by Trimmomatic and merged by FLASH [58]. Operational taxonomic units (OTUs) with 97\% similarity cutoff were clustered using UPARSE (version 7.1, http://drive5.com/uparse/), and chimeric sequences were identified and removed. The abundance of OTUs was rarefied to the lowest number of shared OTUs to remove the effect of sequencing depth across samples. The taxonomy of each $16 \mathrm{~S}$ gene sequence was analyzed using the UNITE (version7.2) database with a confidence threshold of $70 \%$ [59].

\section{Statistical analyses}

Shannon and Chao indices were calculated by Mothur version v.1.30 (http://www.mothur.org/) in R with the vegan package to compare the alpha diversity of soil microbial communities. Principal coordinate analysis ( $\mathrm{PCOA}$ ) was performed in R (version 3.0.2; R Core) using Bray-Curtis distances to compare soil microbial communities. Circos figures were obtained from Circos-0.67-7 (http://circos.ca/) and reflected the proportion of prominent genera in each sample [60]. Redundancy analysis (RDA) was executed in R to analyze the relationship between dominant (abundance $>1 \%$ ) genera or function at KEGG level 2 and environmental factors. Viral genes of virus were picked out to create a viral gene set to analyze the relative abundance of viruses and its functions in soil virus. Data normally distributed were tested for significant differences with Tukey test after a one-way analysis of variance (ANOVA); data not normally distributed were tested with nonparametric Kruskal-Wallis test using SPSS version 16.0 (SPSS, Chicago, IL, USA).

\section{Declarations}

\section{Acknowledgements}

Authors thank Dr. B. E. Hazen (Willows End scientific editing and writing, United States) for critically reading and revising the manuscript.

\section{Authors' contributions}

Y. W. Conceptualization, Methodology, Investigation, Writing - original draft. Y. L. Software, Formal analysis, Investigation. Y. W. Software and statistics. N. W. Investigation, bioinformatic and statistics. W. L. Sampling campaign, Investigation. X. W. Conceptualization, Formal analysis, Validation, Writing - review \& editing, Supervision. The authors read and approved the final manuscript.

\section{Corresponding author}

Correspondence to Xifeng Wang

\section{Funding}

This work was funded by the National Key R\&D Program of China: Inter-Governmental S\&T Cooperation Proposal (Grant No. 2019YFE0108500) and the National Natural Science Foundation of China Project U1704234.

\section{Availability of data and materials}

All the raw sequence data for metagenomic sequencing were submitted to the NCBI Sequence Read Archive (http://www.ncbi.nlm.) database under accession number PRJNA732820 and PRJNA780198.

\section{Ethics approval and consent to participate}

The study does not contain any studies with human participants or animals that require specific ethical approval. 


\section{Consent for publication}

Not applicable.

\section{Competing interests}

The authors declare that they have no competing interests.

\section{Author details}

${ }^{1}$ State Key Laboratory for Biology of Plant Diseases and Insect Pests, Institute of Plant Protection, Chinese Academy of Agricultural Sciences, Beijing 100193, China

${ }^{2}$ Institute of Plant Protection, Hebei Academy of Agricultural and Forestry Sciences, Baoding 071000, China

\section{References}

1. Yuan L. Development of hybrid rice to ensure food security. Rice Sci. 2014;21:1-2. https://linkinghub.elsevier.com/retrieve/pii/S1672630813601675.

2. Fang H, Zhang Z, Li D, Liu K, Zhang K, Zhang W, et al. Temporal dynamics of paddy soil structure as affected by different fertilization strategies investigated with soil shrinkage curve. Soil Tillage Res. 2019;187:102-9. https://doi.org/10.1016/j.still.2018.12.006.

3. Liu W, Zhang X, Wu N, Ren Y, Wang X. High diversity and functional complementation of alimentary canal microbiota ensure small brown planthopper to adapt different biogeographic environments. Front Microbiol. 2020;10: 2953 https://www.frontiersin.org/article/10.3389/fmicb.2019.02953/full.

4. Wang Z, Yang Y, Xia Y, Wu T, Zhu J, Yang J, et al. Time-course relationship between environmental factors and microbial diversity in tobacco soil. Sci Rep. 2019;9:1-11. http://dx.doi.org/10.1038/s41598-019-55859-4.

5. De Quadros PD, Zhalnina K, Davis-Richardson A, Fagen JR, Drew J, Bayer C, et al. The effect of tillage system and crop rotation on soil microbial diversity and composition in a subtropical acrisol. Diversity. 2012;4:375-95. http://www.mdpi.com/1424-2818/4/4/375.

6. Wu N, Shi W, Liu W, Gao Z, Han L, Wang X. Differential impact of Bt-transgenic rice plantings on bacterial community in three niches over consecutive years. Ecotoxicol Environ Saf. 2021;223:112569. https://doi.org/10.1016/j.ecoenv.2021.112569.

7. Talbot JM, Bruns TD, Smith DP, Branco S, Glassman SI, Erlandson S, et al. Independent roles of ectomycorrhizal and saprotrophic communities in soil organic matter decomposition. Soil Biol Biochem. 2013;57:282-91. http://dx.doi.org/10.1016/j.soilbio.2012.10.004.

8. Liu D, Wang H, An S, Bhople P, Davlatbekov F. Geographic distance and soil microbial biomass carbon drive biogeographical distribution of fungal communities in Chinese Loess Plateau soils. Sci Total Environ. 2019;660:1058-69. https://doi.org/10.1016/j.scitotenv.2019.01.097.

9. Khan MS, Zaidi A, Ahemad M, Oves M, Wani PA. Plant growth promotion by phosphate solubilizing fungi - current perspective. Arch Agron Soil Sci. 2010;56:73-98. http://www.tandfonline.com/doi/abs/10.1080/03650340902806469.

10. Xu W, Wang K, Wang H, Liu Z, Shi Y, Gao Z, et al. Evaluation of the biocontrol potential of Bacillus sp. WB against Fusarium oxysporum f. sp. niveum. Biol Control. 2020;147:104288. https://doi.org/10.1016/j.biocontrol.2020.104288.

11. Wang Y, Ji L, Li Q, Wu Y, Li C, Kong L, et al. Effects of long-term bare fallow during the winter-wheat growth season on the soil chemical properties, fungal community composition, and the occurrence of maize fungal diseases in North China. Plant Dis. 2021; 105. https://apsjournals.apsnet.org/doi/10.1094/PDIS-11-20-2492-RE.

12. Shi Y, Li Y, Xiang X, Sun R, Yang T, He D, et al. Spatial scale affects the relative role of stochasticity versus determinism in soil bacterial communities in wheat fields across the North China Plain. Microbiome. 2018;6:27. https://microbiomejournal.biomedcentral.com/articles/10.1186/s40168-018-0409-4.

13. Bahram M, Hildebrand F, Forslund SK, Anderson JL, Soudzilovskaia NA, Bodegom PM, et al. Structure and function of the global topsoil microbiome. Nature. 2018;560:233-7. http://www.nature.com/articles/s41586-018-0386-6.

14. Maestre FT, Delgado-Baquerizo M, Jeffries TC, Eldridge DJ, Ochoa V, Gozalo B, et al. Increasing aridity reduces soil microbial diversity and abundance in global drylands. Proc Natl Acad Sci. 2015;112:15684-9. http://www.pnas.org/lookup/doi/10.1073/pnas.1516684112.

15. Parmar K, Dafale N, Pal R, Tikariha H, Purohit H. An Insight into phage diversity at environmental Habitats using comparative metagenomics approach. Curr Microbiol. 2018;75:132-41. http://link.springer.com/10.1007/s00284-017-1357-0.

16. Suttle CA. Marine viruses - major players in the global ecosystem. Nat Rev Microbiol. 2007;5:801-12. http://www.nature.com/articles/nrmicro1750.

17. Brum JR, Sullivan MB. Rising to the challenge: Accelerated pace of discovery transforms marine virology. Nat Rev Microbiol. 2015;13:147-59. http://dx.doi.org/10.1038/nrmicro3404.

18. Mann NH, Cook A, Millard A, Bailey S, Clokie M. Bacterial photosynthesis genes in a virus. Nature. 2003;424:741-1. http://www.nature.com/articles/424741a.

19. Roux S, Brum JR, Dutilh BE, Sunagawa S, Duhaime MB, Loy A, et al. Ecogenomics and potential biogeochemical impacts of globally abundant ocean viruses. Nature. 2016;537:689-93. http://dx.doi.org/10.1038/nature19366.

20. Bi L, Yu D, Du S, Zhang L, Zhang L, Wu C, et al. Diversity and potential biogeochemical impacts of viruses in bulk and rhizosphere soils. Environ Microbiol. 2021;23:588-99. https://onlinelibrary.wiley.com/doi/10.1111/1462-2920.15010.

21. Middelboe M, Brussaard C. Marine viruses: key players in marine ecosystems. Viruses. 2017;9:302. http://www.mdpi.com/1999-4915/9/10/302.

22. Sullivan MB, Lindell D, Lee JA, Thompson LR, Bielawski JP, Chisholm SW. Prevalence and evolution of core photosystem II genes in marine cyanobacterial viruses and their hosts. Moran NA, editor. PLoS Biol. 2006;4:e234. https://dx.plos.org/10.1371/journal.pbio.0040234.

Page 10/16 
23. Han LL, Yu DT, Zhang LM, Wang JT, He JZ. Unique community structure of viruses in a glacier soil of the Tianshan Mountains, China. J Soils Sediments. 2017;17:852-60. http://dx.doi.org/10.1007/s11368-016-1583-2.

24. Jin M, Guo X, Zhang R, Qu W, Gao B, Zeng R. Diversities and potential biogeochemical impacts of mangrove soil viruses. Microbiome. 2019;7:1-15. https://microbiomejournal.biomedcentral.com/articles/10.1186/s40168-019-0675-9.

25. Yu D-T, He J-Z, Zhang L-M, Han L-L. Viral metagenomics analysis and eight novel viral genomes identified from the Dushanzi mud volcanic soil in Xinjiang, China. J Soils Sediments. 2019;19:81-90. http://link.springer.com/10.1007/s11368-018-2045-9.

26. Adriaenssens EM, Kramer R, Van Goethem MW, Makhalanyane TP, Hogg I, Cowan DA. Environmental drivers of viral community composition in Antarctic soils identified by viromics. Microbiome. 2017;5:83. http://microbiomejournal.biomedcentral.com/articles/10.1186/s40168-017-0301-7.

27. Wolters V, Silver WL, Bignell DE, Coleman DC, Lavelle P, Van Der Putten WH, et al. Effects of global changes on above- and belowground biodiversity in terrestrial ecosystems: Implications for ecosystem functioning. Bioscience. 2000;50:1089-98. http://10.1641/00063568(2000)050[1089:EOGCOA]2.0.CO;2.

28. Wardle DA, Bardgett RD, Klironomos JN, Setälä H, van der Putten WH, Wall DH. Ecological linkages between aboveground and belowground biota. Science (80-). 2004;304:1629-33. https://www.science.org/doi/10.1126/science.1094875.

29. Jing X, Sanders NJ, Shi Y, Chu H, Classen AT, Zhao K, et al. The links between ecosystem multifunctionality and above- and belowground biodiversity are mediated by climate. Nat Commun. 2015;6:8159. http://www.nature.com/articles/ncomms9159.

30. Fierer N, Leff JW, Adams BJ, Nielsen UN, Bates ST, Lauber CL, et al. Cross-biome metagenomic analyses of soil microbial communities and their functional attributes. Proc Natl Acad Sci. 2012;109:21390-5. http://www.pnas.org/cgi/doi/10.1073/pnas.1215210110.

31. Melotto M, Underwood W, He SY. Role of stomata in plant innate immunity and foliar bacterial diseases. Annu Rev Phytopathol. 2008;46:101-22. https://www.annualreviews.org/doi/10.1146/annurev.phyto.121107.104959.

32. Williamson KE, Radosevich M, Smith DW, Wommack KE. Incidence of lysogeny within temperate and extreme soil environments. Environ Microbiol. 2007;9:2563-74. https://onlinelibrary.wiley.com/doi/10.1111/j.1462-2920.2007.01374.x.

33. Wen K, Ortmann AC, Suttle CA. Accurate estimation of viral abundance by epifluorescence microscopy. Kevin Wen. 2004;70:3862-7. http://www.jove.com/video/52781/an-optimized-enrichment-technique-for-isolation-arthrobacter.

34. Zhuang J, Jin Y. Virus retention and transport through Al-oxide coated sand columns: effects of ionic strength and composition. J Contam Hydrol. 2003;60:193-209. https://linkinghub.elsevier.com/retrieve/pii/S0169772202000876.

35. Loveland J, Ryan J, Amy G, Harvey R. The reversibility of virus attachment to mineral surfaces. Colloids Surfaces A Physicochem Eng Asp. 1996;107:205-21. https://linkinghub.elsevier.com/retrieve/pii/0927775795033734.

36. Zünd M, Ruscheweyh H-J, Field CM, Meyer N, Cuenca M, Hoces D, et al. High throughput sequencing provides exact genomic locations of inducible prophages and accurate phage-to-host ratios in gut microbial strains. Microbiome. 2021;9:77.

https://microbiomejournal.biomedcentral.com/articles/10.1186/s40168-021-01033-w.

37. Williamson KE, Radosevich M, Wommack KE. Abundance and diversity of viruses in six delaware soils. Appl Environ Microbiol. 2005;71:3119-25. https://journals.asm.org/doi/10.1128/AEM.71.6.3119-3125.2005.

38. Gómez P, Buckling A. Bacteria-phage antagonistic coevolution in soil. Science. 2011;332:106-9. https://www.science.org/doi/10.1126/science.1198767.

39. Zhang J, Gao Q, Zhang Q, Wang T, Yue H, Wu L, et al. Bacteriophage-prokaryote dynamics and interaction within anaerobic digestion processes across time and space. Microbiome. 2017;5:57. http://microbiomejournal.biomedcentral.com/articles/10.1186/s40168-017-0272-8.

40. Wigington $\mathrm{CH}$, Sonderegger D, Brussaard CPD, Buchan A, Finke JF, Fuhrman JA, et al. Re-examination of the relationship between marine virus and microbial cell abundances. Nat Microbiol. 2016;1:15024. http://www.nature.com/articles/nmicrobiol201524.

41. Howard-Varona C, Hargreaves KR, Abedon ST, Sullivan MB. Lysogeny in nature: mechanisms, impact and ecology of temperate phages. ISME J. 2017;11:1511-20. http://dx.doi.org/10.1038/ismej.2017.16.

42. Gonzalez-Martin C, Teigell-Perez N, Lyles M, Valladares B, Griffin DW. Epifluorescent direct counts of bacteria and viruses from topsoil of various desert dust storm regions. Res Microbiol. 2013;164:17-21. http://dx.doi.org/10.1016/j.resmic.2012.08.009.

43. Zablocki O, Adriaenssens EM, Cowan D. Diversity and ecology of viruses in hyperarid desert soils. Löffler FE, editor. Appl Environ Microbiol. 2016;82:7707. https://journals.asm.org/doi/10.1128/AEM.02651-15.

44. Fierer N, Breitbart M, Nulton J, Salamon P, Lozupone C, Jones R, et al. Metagenomic and small-subunit rRNA analyses reveal the genetic diversity of bacteria, archaea, fungi, and viruses in soil. Appl Environ Microbiol. 2007;73:7059-66. https://journals.asm.org/doi/10.1128/AEM.00358-07.

45. Braga LPP, Spor A, Kot W, Breuil M-C, Hansen LH, Setubal JC, et al. Impact of phages on soil bacterial communities and nitrogen availability under different assembly scenarios. Microbiome. 2020;8:52. https://microbiomejournal.biomedcentral.com/articles/10.1186/s40168-020-00822-z.

46. Wei X, Ge T, Wu C, Wang S, Mason-Jones K, Li Y, et al. T4-like phages reveal the potential role of viruses in soil organic matter mineralization. Environ Sci Technol. 2021;55:6440-8. https://pubs.acs.org/doi/10.1021/acs.est.0c06014.

47. Dalcin Martins P, Danczak RE, Roux S, Frank J, Borton MA, Wolfe RA, et al. Viral and metabolic controls on high rates of microbial sulfur and carbon cycling in wetland ecosystems. Microbiome. 2018;6:1-17. https://microbiomejournal.biomedcentral.com/articles/10.1186/s40168-018-0522-4.

48. Kimura M, Jia Z-J, Nakayama N, Asakawa S. Ecology of viruses in soils: past, present and future perspectives. Soil Sci Plant Nutr. 2008;54:1-32. http://www.tandfonline.com/doi/abs/10.1111/j.1747-0765.2007.00197.x.

49. Hurwitz BL, U’Ren JM. Viral metabolic reprogramming in marine ecosystems. Curr Opin Microbiol. 2016;31:161-8. http://dx.doi.org/10.1016/j.mib.2016.04.002.

Page $11 / 16$ 
50. Emmerling M, Dauner M, Ponti A, Fiaux J, Hochuli M, Szyperski T, et al. Metabolic flux responses to pyruvate kinase knockout in Escherichia coli. J Bacteriol. 2002;184:152-64. https://journals.asm.org/doi/10.1128/JB.184.1.152-164.2002.

51. Trubl G, Jang H, Bin, Roux S, Emerson JB, Solonenko N, Vik DR, et al. Soil viruses are underexplored players in ecosystem carbon processing. bioRxiv. 2018;3:1-21. https://sci-hub.se/10.1128/msystems.00076-18.

52. Rajarajeswari NVL, Muralidharan K. Assessments of farm yield and district production loss from bacterial leaf blight epidemics in rice. Crop Prot. 2006;25:244-52. https://linkinghub.elsevier.com/retrieve/pii/S0261219405001420.

53. Walkley A, Black IA. An examination of the degtjareff method for determining soil organic matter, and a proposed modification of the chromic acid titration method. Soil Sci. 1934;37:29-38. http://journals.Iww.com/00010694-193401000-00003.

54. Hanway JJ. Growth Stages of Corn (Zea mays, L.) 1. Agron J. 1963;55:487-92. https://onlinelibrary.wiley.com/doi/10.2134/agronj1963.00021962005500050024x.

55. Liu J, Yu Z, Wang X, Jin J, Liu X, Wang G. The distribution characteristics of the major capsid gene (g23) of T4-type phages in paddy floodwater in Northeast China. Soil Sci Plant Nutr. 2016;62:133-9. http://www.tandfonline.com/doi/full/10.1080/00380768.2016.1163507.

56. Cross T, Schoff C, Chudoff D, Graves L, Broomell H, Terry K, et al. An optimized enrichment technique for the isolation of Arthrobacter bacteriophage species from soil sample isolates. J Vis Exp. 2015;2015:1-9. http://www.jove.com/video/52781/an-optimized-enrichment-technique-for-isolationarthrobacter.

57. Summer EJ, Liu M, Gill JJ, Grant M, Chan-Cortes TN, Ferguson L, et al. Genomic and functional analyses of Rhodococcus equi phages ReqiPepy6, ReqiPoco6, ReqiPine5, and ReqiDocB7. Appl Environ Microbiol. 2011;77:669-83. https://journals.asm.org/doi/10.1128/AEM.01952-10.

58. Magoc T, Salzberg SL. FLASH: fast length adjustment of short reads to improve genome assemblies. Bioinformatics. 2011;27:2957-63. https://academic.oup.com/bioinformatics/article-lookup/doi/10.1093/bioinformatics/btr507.

59. Kõljalg U, Nilsson RH, Abarenkov K, Tedersoo L, Taylor AFS, Bahram M, et al. Towards a unified paradigm for sequence-based identification of fungi. Mol Ecol. 2013;22:5271-7. http://doi.wiley.com/10.1111/mec.12481.

60. Krzywinski M, Schein J, Birol I, Connors J, Gascoyne R, Horsman D, et al. Circos: An information aesthetic for comparative genomics. Genome Res. 2009;19:1639-45. http://genome.cshlp.org/lookup/doi/10.1101/gr.092759.109.

\section{Figures}

A

Circos

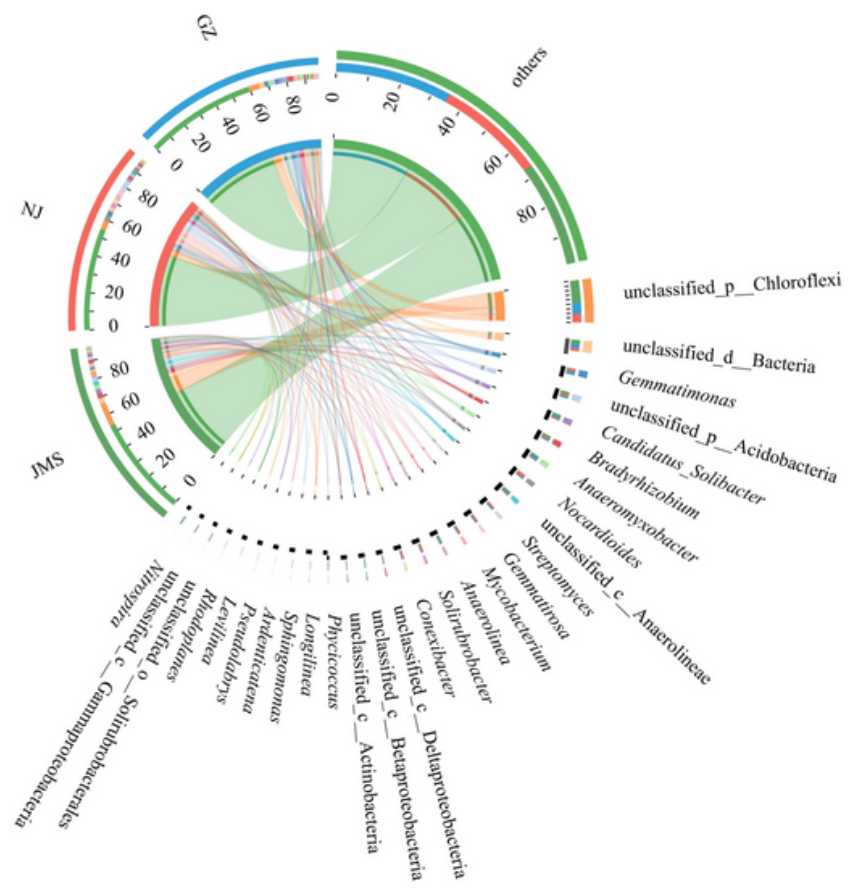

B

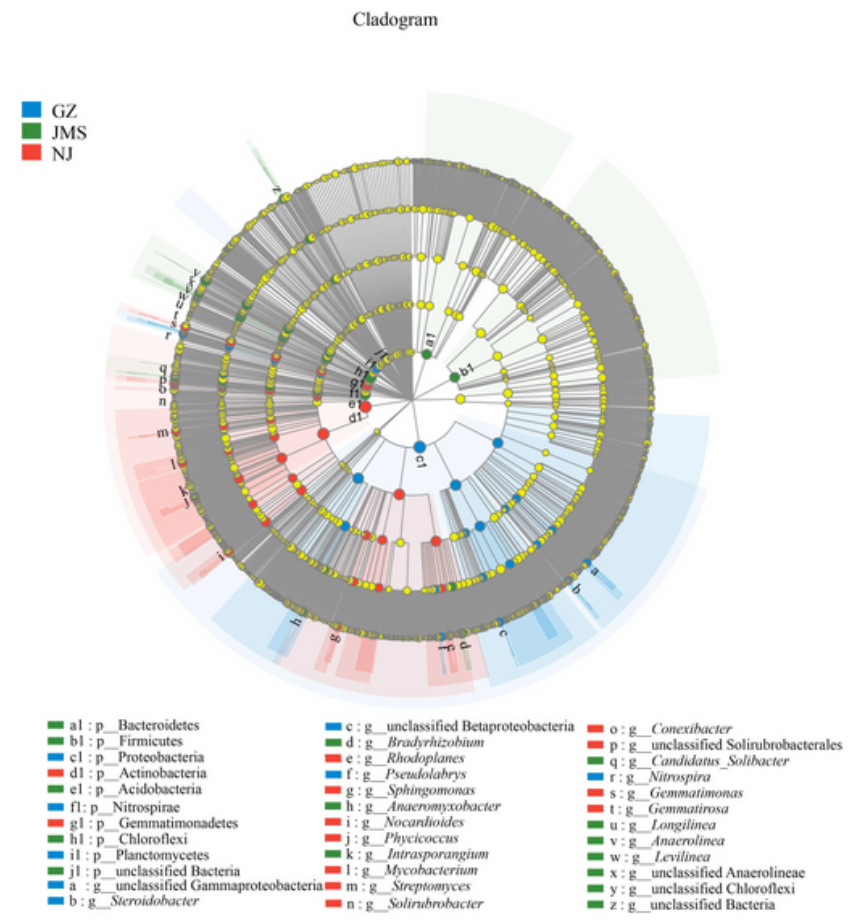

\section{Figure 1}

Differential analysis of soil microbial composition in three rice agroecosystems in China. (A): Circos analysis of distribution and proportion of the microbial dominant genera. In top left half of circle, numbers are relative abundance of genera in the three agroecosystems (GZ: rice double cropping in Guangzhou in blue; JMS: rice single cropping in Jiamusi in red; $\mathrm{NJ}$ : rice-wheat rotation cropping in Nanjing; others: genera with abundance less than $1 \%$ were merged and indicated as others). In lower right, the axis represents the distribution proportion of a genus in each agroecosystem. (B): Linear discriminant effect size analysis identified remarkable enrichment of taxa from phylum to genus level. Different color nodes represent the microbial groups that are significantly 
higher in the corresponding groups and have a significant influence on the difference between the groups. Light yellow nodes represent the microbial groups that contribute no significant difference in different groups or influence on the difference between groups.
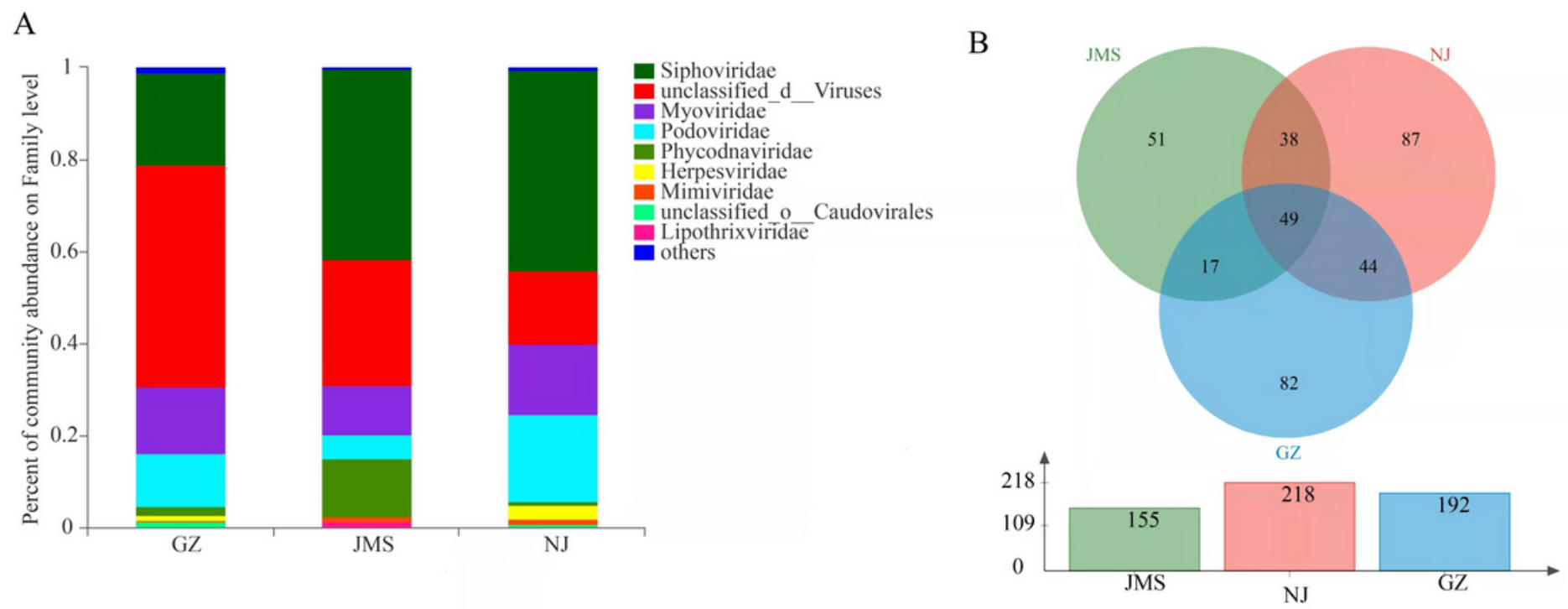

\section{Figure 2}

Differential analysis of soil viral composition in three rice agroecosystems in China. (A) Relative abundance of main soil viral families in the three rice agroecosystems in China. (B) Venn diagram showing the number of viral species shared and unique among different rice agroecosystems. GZ: rice double cropping in Guangzhou in blue; JMS: rice single cropping in Jiamusi in red; NJ: rice-wheat rotation cropping in Nanjing.

A

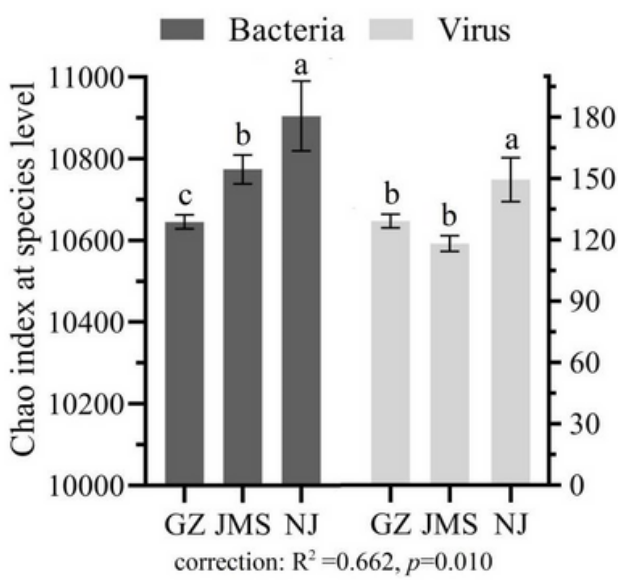

B

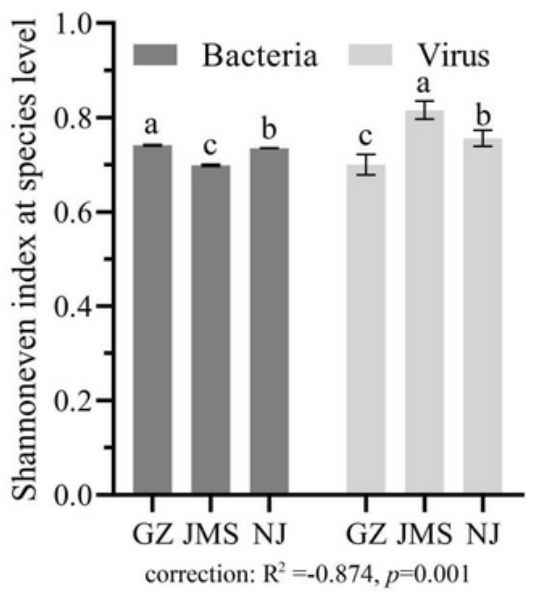

\section{Figure 3}

Alpha diversity of soil bacterial and viral communities. Variation in alpha diversity of soil bacterial community and viral community and (C) Chao index and (D) Shannon index. GZ: rice double cropping in Guangzhou in blue; JMS: rice single cropping in Jiamusi in red; NJ: rice-wheat rotation cropping in Nanjing. 
A

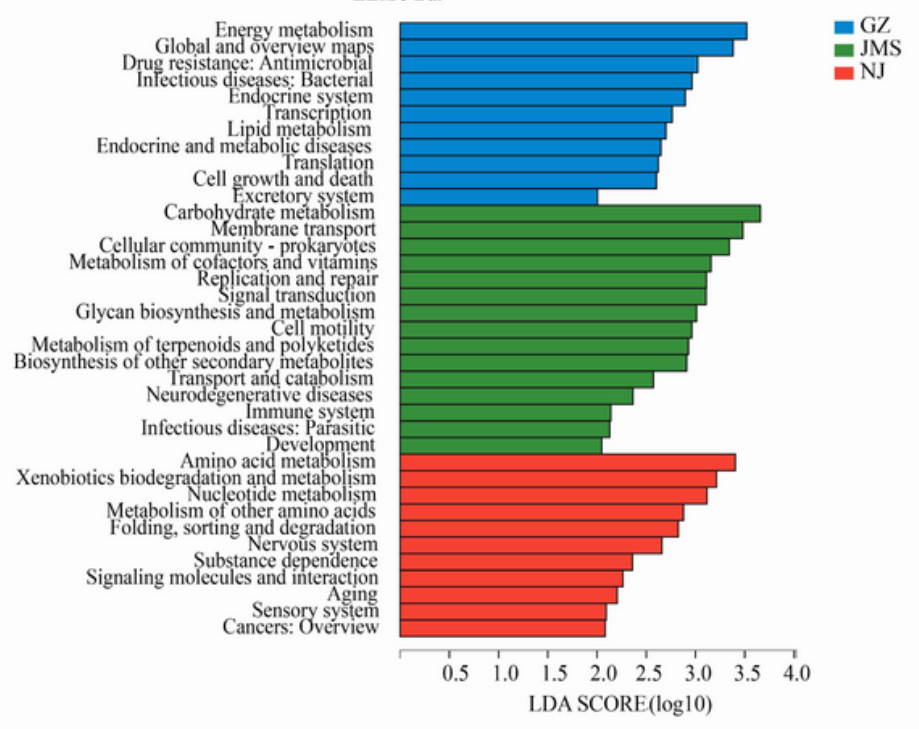

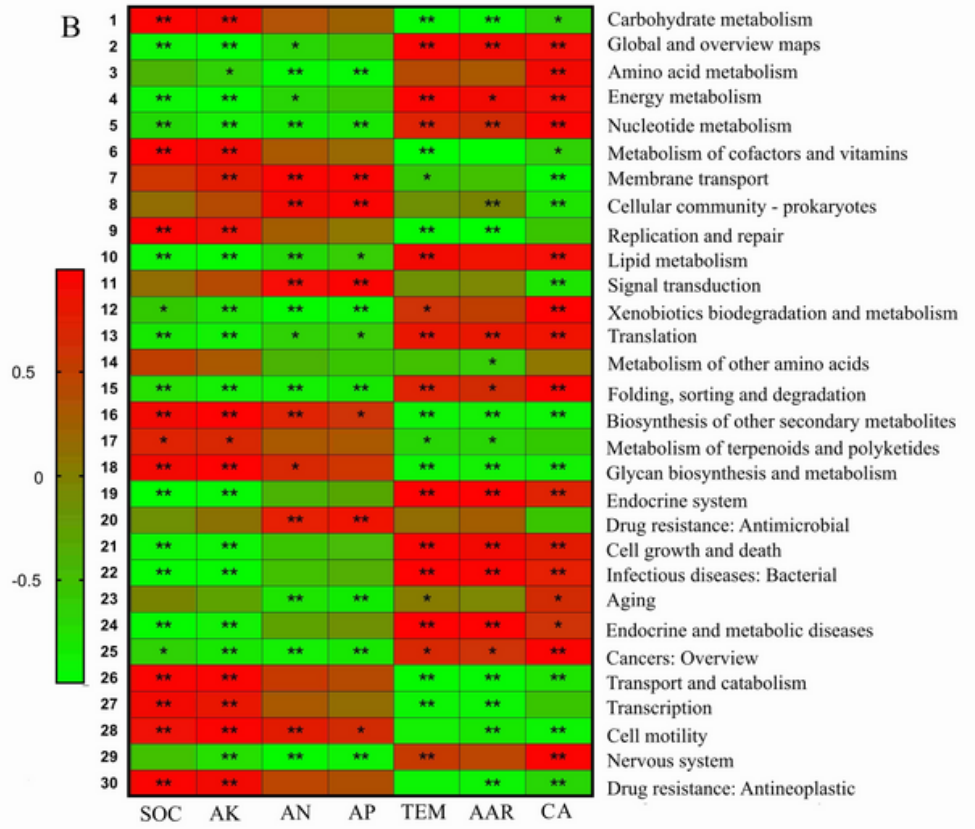

Figure 4

Analysis of differences in soil bacterial functions and correlation analysis with environmental factors in the three rice agroecosystems. (A) Linear discriminant analysis of soil bacterial function at KEGG level 2. (B) Redundancy analysis showing the influence of environmental factors on soil bacterial function at KEGG level 2. GZ: rice double cropping in Guangzhou in blue; JMS: rice single cropping in Jiamusi in red; NJ: rice-wheat rotation cropping in Nanjing. SOC: soil organic carbon; AK: available potassium, AN: available nitrogen; AP: available phosphorus; TEM: annual accumulated temperature; AAR: annual precipitation; CA: chemical pesticides application.

A
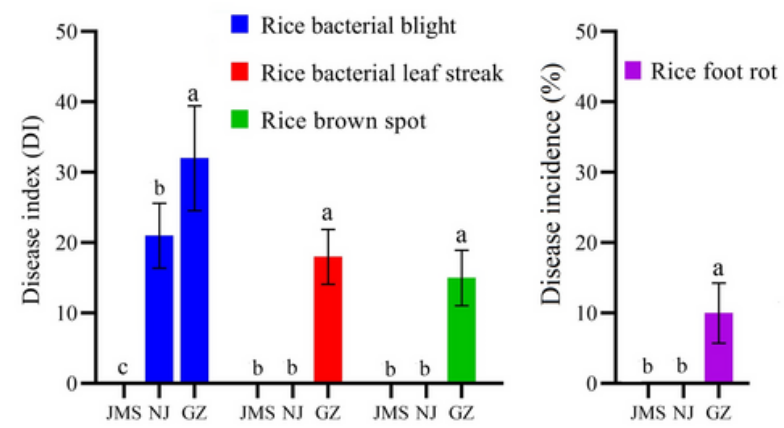

C

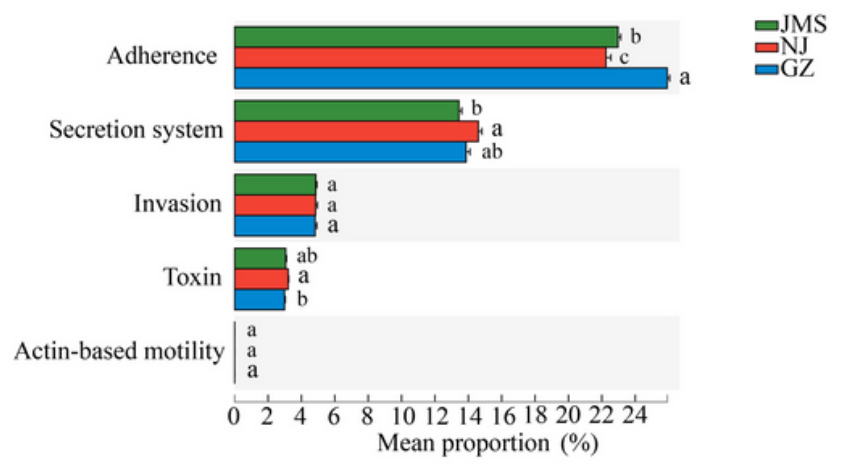

B

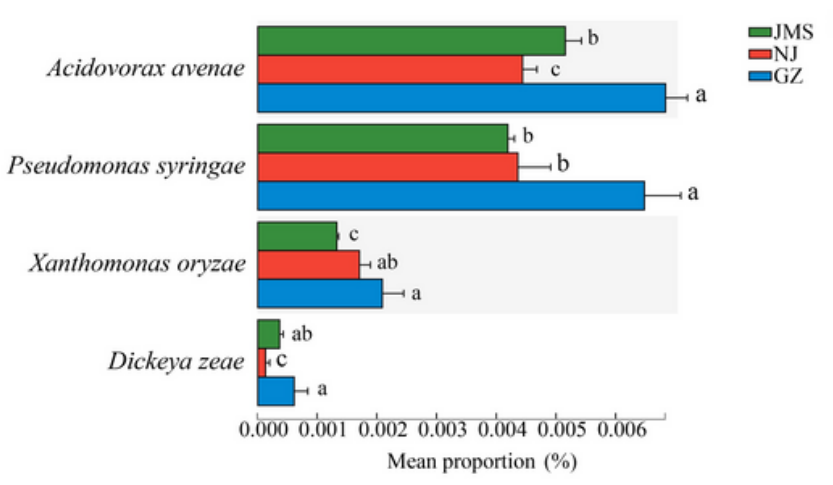

D

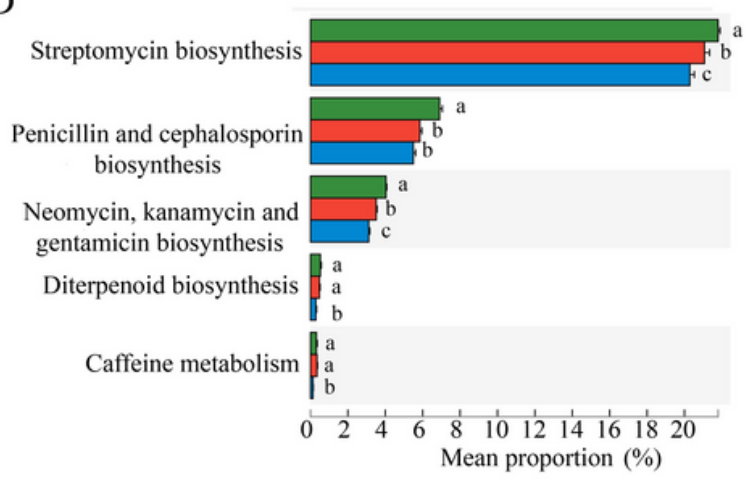


Rice bacterial diseases and differences in soil bacterial function related to bacterial disease severity in the three agroecosystems in China. (A): Disease index for four diseases. Relative abundance of (B) potentially pathogenic bacteria and genes related to (C) virulence factors and (D) secondary metabolite biosynthesis. Different letters above the bars indicate a significant difference $(p<0.05)$ according to Kruskal-Wallis $\mathrm{H}$ test. GZ: rice double cropping in Guangzhou in blue; JMS: rice single cropping in Jiamusi in red; $\mathrm{NJ}$ : rice-wheat rotation cropping in Nanjing.

A

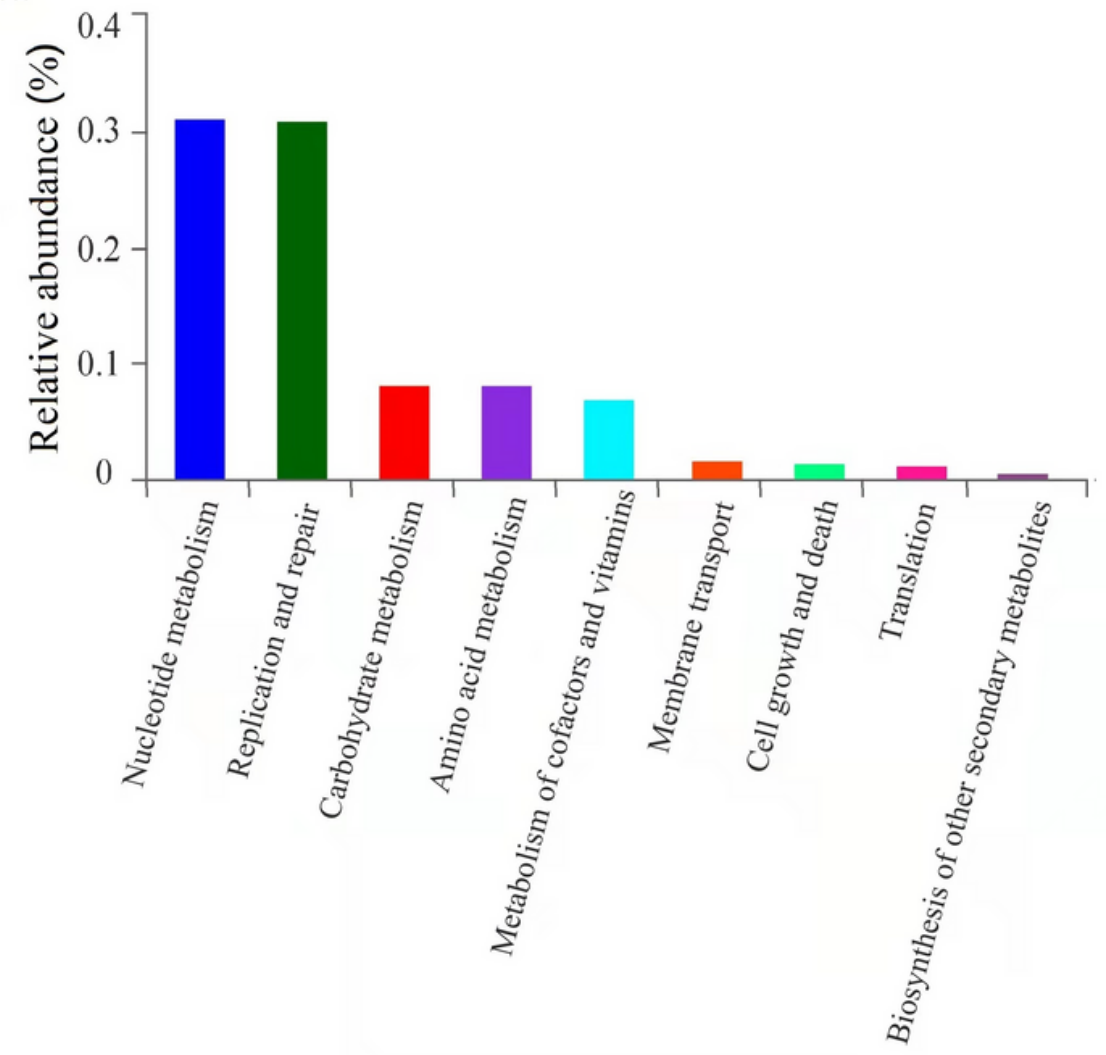

B

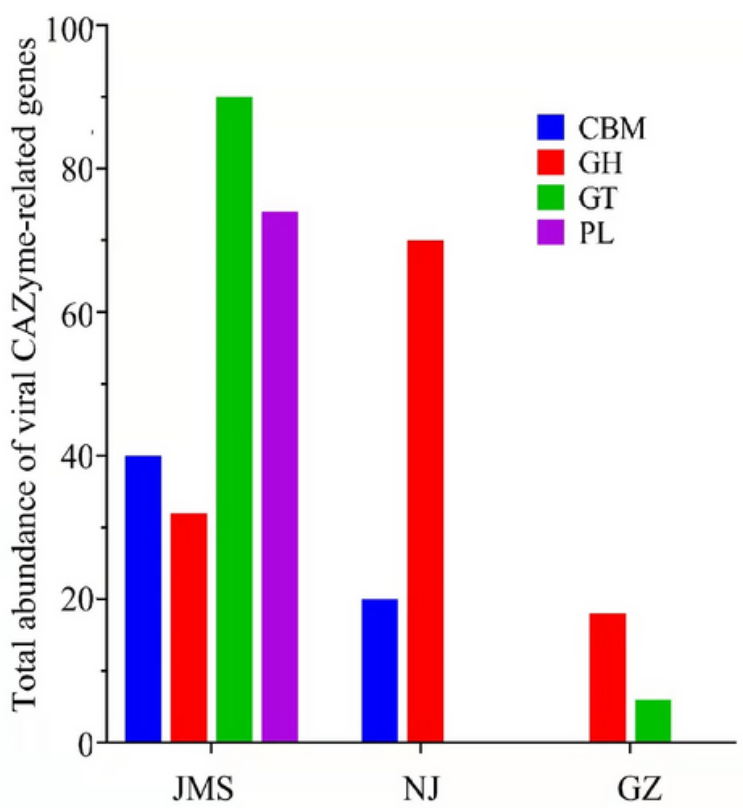

\section{Figure 6}

Abundant auxiliary carbohydrate metabolism genes in paddy soil viruses. Functional annotation of paddy soil virome. (A) Functional annotation was predicted with KEGG database (E-value $<1 \mathrm{e}^{-5}$ ). KEGG function class was ordered according to their hit frequency. (B) Annotation of viral carbohydrate metabolism-related ORFs in the CAZy database. GZ: rice double cropping in Guangzhou in blue; JMS: rice single cropping in Jiamusi in red; NJ: rice-wheat rotation cropping in Nanjing. CBM: carbohydrate-binding modules; GH: glycoside hydrolases; GT: glycosyl transferases; PL: polysaccharide lyases. 
A
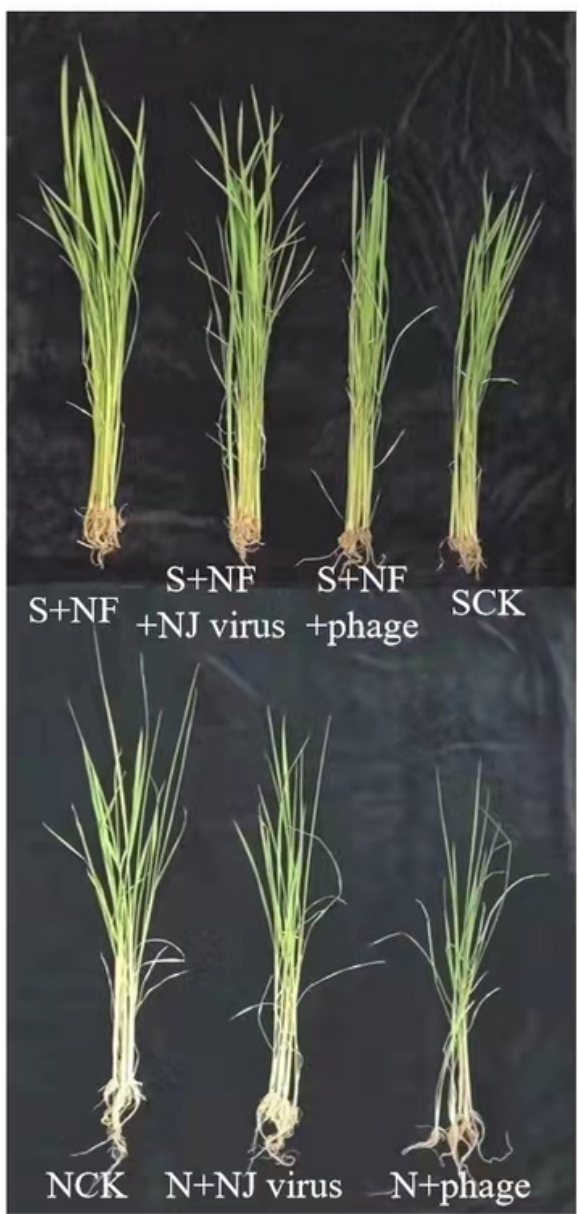

B

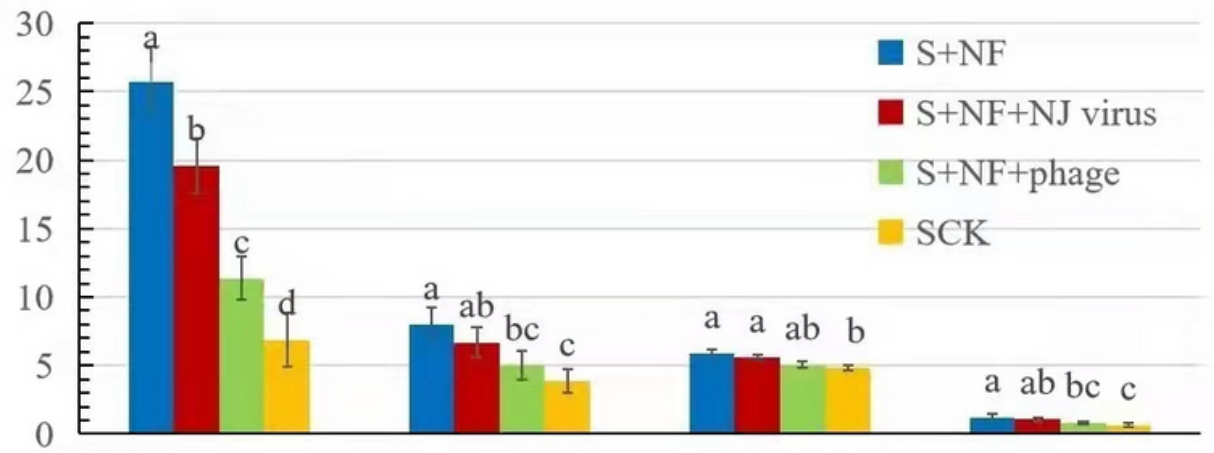

Nitrogen fixation Nitrogen content Plant height $\mathrm{C}_{2} \mathrm{H}_{4} \mathrm{nmol} /(\mathrm{g} \cdot \mathrm{h}) \quad 10^{-3} \mathrm{~g}$ $\mathrm{cm}$

Dry weight g

C

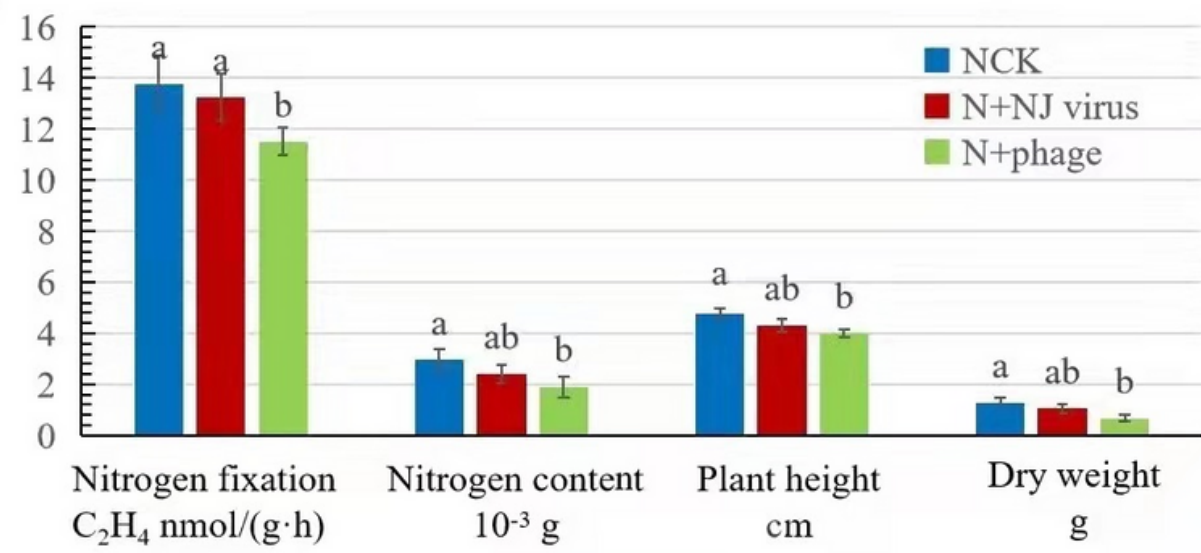

\section{Figure 7}

Addition of Enterobacter bacteriophage-NJ to soil reduced nitrogen-fixation capacity of Enterobacter species and inhibited rice growth. (A) (top row) Representative phenotypes of rice grown in sterile field soil amended with $\mathrm{N}$-fixing Enterobacter(S+NF), virus isolated from Nanjing soil and $\mathrm{N}$-fixing Enterobacter(S+NF+virus), Enterobacter bacteriophage and N-fixing Enterobacter(S+NF+phage), or in sterile field soil (SCK) and (B) effects of the treatments on $\mathrm{N}$ fixation, rice $\mathrm{N}$ content, plant height and dry mass. (A) (bottom row) Representative phenotypes of rice grown in sterile field soil from Nanjing (NCK) or in Nanjing soil amended with virus isolated from Nanjing soil ( $\mathrm{N}+\mathrm{NJ}$ virus) or with Enterobacter bacteriophage ( $\mathrm{N}+$ phage) and (C) effects of treatments on $\mathrm{N}$ fixation, rice $\mathrm{N}$ content, plant height and dry mass. Different letters above the bars indicate a significant difference $(p<0.05)$ according to Kruskal-Wallis $\mathrm{H}$ test.

\section{Supplementary Files}

This is a list of supplementary files associated with this preprint. Click to download.

- WangXSupportingInformation.pdf 